\title{
Synthesis and catalytic properties of manganese(II) and oxovanadium(IV) complexes anchored to mesoporous MCM-41
}

\author{
Tiago A. Fernandes a , Carla D. Nunes a, Pedro D. Vaz ${ }^{\text {a }}$, Maria José Calhorda ${ }^{\text {a }}$, \\ Paula Brandão ${ }^{\mathrm{b}}$, João Rocha ${ }^{\mathrm{b}}$, Isabel S. Gonçalves ${ }^{\mathrm{b}}$, Anabela A. Valente ${ }^{\mathrm{b}}$, \\ Liliana P. Ferreira ${ }^{c, d}$, Margarida Godinho ${ }^{c}$, Paula Ferreira ${ }^{\mathrm{e}, *}$ \\ a Department of Chemistry and Biochemistry, CQB, Faculty of Sciences of the University of Lisbon, Campo Grande, 1749-016 Lisboa, Portugal \\ ${ }^{\mathrm{b}}$ Department of Chemistry, CICECO, University of Aveiro, 3810-193 Aveiro, Portugal \\ ${ }^{\mathrm{c}}$ CFMC-UL/Department of Physics, Faculty of Science of the University of Lisbon Ed. C8, Campo Grande, 1749-016 Lisboa, Portugal \\ ${ }^{\mathrm{d}}$ Department of Physics, Faculty of Sciences and Technology, University of Coimbra, 3004-516 Coimbra, Portugal \\ ${ }^{\mathrm{e}}$ Department of Ceramics and Glass Engineering, CICECO, University of Aveiro, 3810-193 Aveiro, Portugal
}

Received 25 June 2007; received in revised form 4 September 2007; accepted 5 September 2007

Available online 14 September 2007

\begin{abstract}
Reaction of $\left[\mathrm{Mn}^{\mathrm{III}}(\mathrm{acac})_{3}\right]$ and $\left[\mathrm{V}^{\mathrm{IV}} \mathrm{O}(\mathrm{acac})_{2}\right]$ with the 1,4-diazabutadiene $(\mathrm{DAB})$ ligands $\mathrm{Ph}-\mathrm{DAB}-(\mathrm{CH})_{3} \mathrm{R}\left[\mathrm{R}=\mathrm{Si}(\mathrm{OEt})_{3}(\mathbf{1 a})\right.$; $\mathrm{H}$ $(\mathbf{1 b})](\mathrm{L})$ leads to complexes of the type $\left[\mathrm{Mn}^{\mathrm{II}}(\mathrm{acac})_{2} \mathrm{~L}\right]$ and $\left[\mathrm{V}^{\mathrm{IV}} \mathrm{O}(\mathrm{acac}) \mathrm{L}\right] \mathrm{Cl}$ in good yields. These complexes were characterised by spectroscopic techniques, and magnetic measurements showed that in the case of the manganese the metal was reduced during the reaction with the nitrogen ligand.

The oxovanadium and manganese complexes bearing the ligand with triethoxysilyl groups $\mathrm{Ph}-\mathrm{DAB}-(\mathrm{CH})_{3} \mathrm{Si}(\mathrm{OEt})_{3}(\mathbf{1 a})$ were immobilised in ordered MCM-41 by carrying out a grafting reaction. Tethered complexes of the same type were prepared by treating MCM-41 first with a toluene solution of 1a under reflux; manganese(III) and oxovanadium(IV) precursors were then introduced into the MCM-41-ligand by pore volume impregnation of complex solutions. The modified materials were characterised by powder X-ray diffraction, solid-state NMR $\left({ }^{13} \mathrm{C},{ }^{29} \mathrm{Si}\right)$, FTIR, thermogravimetric studies and low temperature nitrogen adsorption isotherms. The grafted materials contained $0.7 \mathrm{wt} \% \mathrm{Mn}$ and $0.8 \mathrm{wt} \% \mathrm{~V}$, while higher metal loadings were achieved when the materials were prepared by tethering $(2.9 \mathrm{wt} \% \mathrm{Mn}$ and $2.4 \mathrm{wt} \% \mathrm{~V})$.

The modified materials are active catalysts for the oxidation of cis-cyclooctene using tert-butylhydroperoxide as oxygen donor, at $328 \mathrm{~K}$, yielding 1,2-epoxycyclooctane as the main reaction product and 1,2-cyclooctanediol as a by-product. The vanadium-containing materials are more efficient epoxidation catalysts than the manganese ones. The catalytic behaviour of the heterogenised catalysts was also compared with that observed in homogeneous phase for the complexes $\left[\mathrm{Mn}(\mathrm{acac})_{2} \mathrm{~L}\right]$ and $[\mathrm{VO}(\operatorname{acac}) \mathrm{L}] \mathrm{Cl}$. The vanadium catalysts exhibited the highest catalytic activity, whereas the manganese catalysts were the least active and selective to epoxide formation.
\end{abstract}

(C) 2007 Elsevier Inc. All rights reserved.

Keywords: Mesoporous materials; MCM-41; Manganese; Oxovanadium; Nitrogen ligands; Epoxidation

\section{Introduction}

Amorphous silica, alumina and other inorganic oxides have their surface covered by hydroxyl groups, which can

\footnotetext{
${ }^{*}$ Corresponding author. Tel.: +351 234 370264; fax: +351 234425300. E-mail address: pcferreira@ua.pt (P. Ferreira).
}

be easily functionalised by reaction with appropriate molecules, and have thus found widespread applications as supports for species active in a variety of processes $[1,2]$. Properties such as the high specific surface area, mechanical stability, and promotion of well-dispersed active sites, make these supports interesting [2]. The discovery of ordered mesoporous materials in 1992 led to a resurgence in the area of supported reagents [3,4], with the emergence 
of micelle-templated inorganic oxides as promising alternatives [5]. These materials present as additional advantages relative to amorphous silicas, the fact that the ordered mesopores and higher specific surface area may allow higher loadings of supported reagents, improve active site accessibility and allow catalytic reactions to occur in constrained environments (for example, those involving bulky substrate and/or product molecules, in liquid phase) [6]. These materials have been used as hosts for the immobilisation of coordination compounds to be applied in several fields, such as catalysis and photo- or electro-chemistry $[7,8]$. Several works concerning the derivatisation of hexagonally ordered mesoporous MCM-41 for catalysis purposes can be found in the literature $[9,10]$, offering the advantages of easy recovery and reuse of the catalyst. The application of MCM-41-supported Mo(VI) complexes, prepared by grafting and tethering techniques, as catalysts for olefin epoxidation, has been well documented [11-14]. The use of these host materials to support magnetically active derivatives of first row transition metals has been less investigated.

Compounds of $\mathrm{Mn}(\mathrm{II} / \mathrm{III})$ and V(IV) play vital and versatile roles in the redox biochemistry of many organisms $[15,16]$. Manganese is the metal centre in enzymes such as catalase, superoxidase and dismutase, while vanadium plays an important role in haloperoxidases, as well as in nitrogenases, and an increased knowledge of their catalytic activity in oxidation processes can only be advantageous. Porphyrin ligands coordinate several metals, such as $\mathrm{Fe}$, $\mathrm{Mn}$ and $\mathrm{Ni}$, providing environments close to the biological ones $[15,16]$. Simpler bidentate nitrogen donor ligands, as 1,4-diazabutadienes (DAB), are also versatile since their electronic and steric properties may be fine-tuned by changing the nature of the substituent groups.

Both a pure silica and an aluminosilicate MCM-41 were the supports taken by Luan et al. [17] to immobilise 2,2'bipyridine manganese(II) complexes $\left[\mathrm{MnL}_{2}\right]$ using an impregnation technique. The heterogeneous complexes were effective active sites for oxidation-reduction reactions at low temperature. A Mn(III) complex was also reported as having been immobilised onto the surface of MCM-41 [18] by a tethering approach. First, a functionalised ligand was covalently bound to the surface and then the metal species was directly added to this ligand, forming the complex directly inside the mesoporous material. Several complexes of Mo bearing DAB ligands have been successfully immobilised on the surface of ordered mesoporous silicas by grafting or tethering techniques, for application as catalysts for polymerisation reactions [19] and epoxidation of olefins [14].

In the present work, the immobilisation of manganese and vanadium complexes bearing 1,4-diazabutadiene ligands on MCM-41 host materials by grafting and tethering techniques, is described. A comparative study of the final hybrid mesostructured materials obtained by the two techniques was carried out, by means of solid-state techniques and determination of magnetic properties. The unsupported complexes were also synthesised and charac- terised. The catalytic performance of all prepared materials was investigated in the oxidation of cis-cyclooctene with tert-butylhydroperoxide $(t-\mathrm{BuOOH})$.

\section{Experimental section}

\subsection{Materials and methods}

Starting materials were obtained from commercial sources and used as received. All preparations and manipulations were carried out using standard Schlenk techniques under nitrogen. Solvents were dried by standard procedures (toluene, methanol, and diethyl ether with $\mathrm{Na}$ /benzophenone ketyl; $\mathrm{CH}_{2} \mathrm{Cl}_{2}$ with $\mathrm{CaH}_{2}$ ), distilled under nitrogen and kept over $4 \AA$ molecular sieves. Elemental analysis was performed at the University of Vigo. Powder X-ray diffraction (PXRD) data was collected on a Phillips PW 1710 diffractometer using $\mathrm{Cu}-\mathrm{K} \alpha$ radiation. The thermal studies were performed using a TG-DSC 111 from Setaram at a heating rate of $10 \mathrm{~K} \mathrm{~min}^{-1}$ under nitrogen. ${ }^{29} \mathrm{Si}$ solid-state NMR spectra were recorded at 79.49 MHz, on a (9.4 T) Bruker Avance 400P spectrometer. ${ }^{29} \mathrm{Si}$ MAS NMR spectra were recorded with $40^{\circ}$ pulses, a spinning rate of $5.0 \mathrm{kHz}$, and $60 \mathrm{~s}$ recycle delays. ${ }^{29} \mathrm{Si} \mathrm{CP}$ MAS NMR spectra were recorded with $4 \mu \mathrm{s}{ }^{1} \mathrm{H} 90^{\circ}$ pulses, $8 \mathrm{~ms}$ contact time, a spinning rate of $5 \mathrm{kHz}$, and $4 \mathrm{~s}$ recycle delays. ${ }^{13} \mathrm{C}$ CP MAS NMR spectra were recorded with a $4.5 \mu \mathrm{s}{ }^{1} \mathrm{H} 90^{\circ}$ pulse, $2 \mathrm{~ms}$ contact time, a spinning rate of $7 \mathrm{kHz}$, and $4 \mathrm{~s}$ recycle delays. Chemical shifts are quoted in ppm from TMS. ${ }^{13} \mathrm{C}$ CP MAS NMR spectra were also recorded in the solid state at $125.76 \mathrm{MHz}$ on a Bruker Avance 500 spectrometer.

TGA studies were performed using a Perkin-Elmer TGA7 thermobalance system at a heating rate of $10 \mathrm{~K} \mathrm{~min}^{-1}$ under nitrogen. FTIR spectra were measured with a Nicolet 6700 FTIR spectrometer using $\mathrm{KBr}$ pellets (for complexes) in transmission mode and also using Diffuse Reflectance (for mesoporous materials). All FTIR spectra were measured using $2 \mathrm{~cm}^{-1}$ resolution.

The precursor complexes $\mathrm{Mn}(\mathrm{acac})_{3}[20]$ and $\mathrm{VO}(\mathrm{acac})_{2}$ [21] were prepared as described previously.

Purely siliceous MCM-41 was synthesised as reported using $\left[\left(\mathrm{C}_{14} \mathrm{H}_{29}\right) \mathrm{N}\left(\mathrm{CH}_{3}\right)_{3}\right] \mathrm{Br}\left(\mathrm{C}_{14} \mathrm{TMABr}\right)$ as the templating agent [6]. Before the grafting experiments with MCM-41, physisorbed water was removed from the calcined material by heating at $453 \mathrm{~K}$ in vacuum $\left(10^{-2} \mathrm{~Pa}\right)$ for $2 \mathrm{~h}$. Ph-DAB$\left(\mathrm{CH}_{2}\right)_{3} \mathrm{R}\left[\mathrm{R}=\mathrm{Si}(\mathrm{OEt})_{3}(\mathbf{1 a}) ; \mathrm{H}(\mathbf{1 b})\right]$ ligands were synthesised by a described procedure [14].

\subsection{Preparation of the complexes of the type $\left[\mathrm{Mn}(\mathrm{acac})_{2}\left\{\mathrm{Ph}-\mathrm{DAB}-\left(\mathrm{CH}_{2}\right)_{3} \mathrm{R}\right\}\right](\mathbf{2 a}, \mathbf{2 b})$ and $\left[\mathrm{VO}(\mathrm{acac})\left\{\mathrm{Ph}-\mathrm{DAB}-\left(\mathrm{CH}_{2}\right)_{3} \mathrm{R}\right\}\right] \mathrm{Cl}(\mathbf{3 a}, \mathbf{3} \boldsymbol{b})$ $\left(\mathrm{R}=\mathrm{Si}(\mathrm{OEt})_{3}, \mathrm{H}\right)$}

A solution of the precursor complexes $\left[\mathrm{Mn}(\mathrm{acac})_{3}\right]$ $(0.70 \mathrm{~g}, 2 \mathrm{mmol})$ or $\left[\mathrm{VO}(\mathrm{acac})_{2}\right](0.53 \mathrm{~g}, 2 \mathrm{mmol})$ in methanol $(10 \mathrm{~mL})$ was treated with 1 equivalent of either ligand 
1a and $\mathbf{1 b}$ in methanol $(10 \mathrm{~mL}) . \mathrm{HCl} 37 \%(0.2 \mathrm{~mL})$ was added to the resulting solution and stirred under reflux for $3 \mathrm{~h}$ under a $\mathrm{N}_{2}$ atmosphere. The solvent was then evaporated, and the resultant solid product washed with $\mathrm{CH}_{2} \mathrm{Cl}_{2}$ and dried in vacuum.

\subsection{1. [ Mn (acac $\left.)_{2}\left\{\mathrm{Ph}-\mathrm{DAB}-\left(\mathrm{CH}_{2}\right)_{3} \mathrm{Si}(\mathrm{OEt})_{3}\right\}\right]$ (2a)}

Yield: $1.57 \mathrm{~g}(90 \%)$. Anal. Calcd for $\mathrm{C}_{42} \mathrm{H}_{66} \mathrm{MnN}_{2} \mathrm{O}_{10} \mathrm{Si}_{2}$ (870.10): C, 57.98; H, 7.65; N, 3.22; Mn, 6.31. Found C, 56.44; H, 8.98; N, 3.29; Mn 6.10. IR ( $\left.\mathrm{KBr}, \mathrm{cm}^{-1}\right): 2939$ (w), $1684(\mathrm{w}), 1604$ (s), 1560 (s), 1536 (vs), 1496 (w), 1449 (m), 1363 (s), $1282(\mathrm{~m}), 1213(\mathrm{~m}), 1190(\mathrm{w}), 1108$ (sh), 1066 (vs), 1025 (vs), 989 (sh), 937 (s), 794 (m), 764 (m), 698 (s), 643 (m). ${ }^{1} \mathrm{H}$ NMR (400 MHz, $\mathrm{CDCl}_{3}$, r.t., TMS): $\delta=0.75\left(\mathrm{~s} \mathrm{bd}, 4 \mathrm{H}, \mathrm{SiCH}_{2}\right), 1.38\left(\mathrm{~m}, 18 \mathrm{H}, \mathrm{OCH}_{2} \mathrm{CH}_{3}\right)$, $1.60\left(\mathrm{~m}, 4 \mathrm{H}, \mathrm{CH}_{2} \mathrm{CH}_{2} \mathrm{CH}_{2}\right), 1.85\left(\mathrm{~s}, 12 \mathrm{H}, \mathrm{CH}_{3}\right.$ acac), 3.05 (s bd, $4 \mathrm{H}, \mathrm{NCH}_{2} ; 12 \mathrm{H}, \mathrm{OCH}_{2} \mathrm{CH}_{3} ; 2 \mathrm{H}$, acac), 7.01$7.27(\mathrm{~m}, 6 \mathrm{H}, \mathrm{Ph}), 7.51(\mathrm{~s}, 4 \mathrm{H}, \mathrm{Ph}) \mathrm{ppm}$.

\subsection{2. [ $\left.\mathrm{Mn}(\mathrm{acac})_{2}\left\{\mathrm{Ph}-\mathrm{DAB}-\left(\mathrm{CH}_{2}\right)_{2} \mathrm{CH}_{3}\right\}\right](\mathbf{2 b})$}

Yield: $1.03 \mathrm{~g}(94 \%)$. IR (KBr, $\left.\mathrm{cm}^{-1}\right)$ : 3449(vs), 3206(w), $3066(\mathrm{w}), 2979$, (w), $2968(\mathrm{w}), 1680(\mathrm{~s}), 1661$ (s), 1596 (vs), $1525(\mathrm{~s}), 1450(\mathrm{~m}), 1342(\mathrm{~s}), 1213(\mathrm{vs}), 1175(\mathrm{w}), 877(\mathrm{~s}), 719$ (s), $697(\mathrm{~m}), 643(\mathrm{~s}) .{ }^{1} \mathrm{H}$ NMR $\left(400 \mathrm{MHz}, \mathrm{CDCl}_{3}\right.$, r.t., TMS): $\delta=0.87 \quad\left(\mathrm{~d}, \quad 6 \mathrm{H}, \quad \mathrm{CH}_{2} \mathrm{CH}_{3}\right), \quad 1.66 \quad(\mathrm{~m}, \quad 4 \mathrm{H}$, $\mathrm{CH}_{2} \mathrm{CH}_{2} \mathrm{CH}_{3}$ ), 1.99 (s, $12 \mathrm{H}, \mathrm{CH}_{3}$ acac), 3.36 (s bd, $4 \mathrm{H}$, $\mathrm{NCH}_{2} ; 2 \mathrm{H}$, acac), 7.23-7.66 (m, 8H, Ph), 7.87-7.95 (m, $2 \mathrm{H}, \mathrm{Ph}) \mathrm{ppm}$.

\subsection{3. [ VOO (acac) $\left.\left\{\mathrm{Ph}-\mathrm{DAB}-\left(\mathrm{CH}_{2}\right)_{3} \mathrm{Si}(\mathrm{OEt})_{3}\right\}\right] \mathrm{Cl}(\mathbf{3 a})$}

Yield: $1.39 \mathrm{~g}(85 \%)$. Anal. Calcd for $\mathrm{C}_{37} \mathrm{H}_{59} \mathrm{ClVN}_{2} \mathrm{O}_{9} \mathrm{Si}_{2}$ (818.45): C, 54.30; H, 7.27; N, 3.42. Found C, 53.88; H, 9.15; N, 3.70. IR $\left(\mathrm{KBr}, \mathrm{cm}^{-1}\right): v 2939(\mathrm{w}), 1684(\mathrm{w}), 1564$ (vs), 1526 (s), 1495 (sh), 1448 (w), 1419 (w), 1372 (s), $1358(\mathrm{~s}), 1287(\mathrm{~m}), 1227(\mathrm{w}), 1190(\mathrm{w}), 1110(\mathrm{vs}), 1070$ (vs), 1027 (vs), 995 (vs), 936 (s), 911 (sh), 798 (m), 790 (m), 762 (m), 699 (m), 687 (sh), 595 (w). ${ }^{1} \mathrm{H}$ NMR (400 MHz, $\mathrm{CDCl}_{3}$, r.t., TMS): $\delta=0.55$ (s bd, $4 \mathrm{H}, \mathrm{SiCH}_{2}$ ), $1.60\left(\mathrm{~m}, 18 \mathrm{H}, \mathrm{OCH}_{2} \mathrm{CH}_{3}\right), 1.60\left(\mathrm{~m}, 4 \mathrm{H}, \mathrm{CH}_{2} \mathrm{CH}_{2} \mathrm{CH}_{2}\right)$, 2.70 (s, $12 \mathrm{H}, \mathrm{CH}_{3} \mathrm{acac}$ ), 3.10 (t, $4 \mathrm{H}, \mathrm{NCH}_{2}$ ), 4.65 (s bd, $\left.12 \mathrm{H}, \mathrm{OCH}_{2} \mathrm{CH}_{3} ; 2 \mathrm{H}, \mathrm{acac}\right), 7.2(\mathrm{~m}, 4 \mathrm{H}, \mathrm{Ph}), 7.4(\mathrm{~s}, 4 \mathrm{H}$, $\mathrm{Ph}), 7.8(\mathrm{~s}, 2 \mathrm{H}, \mathrm{Ph}) \mathrm{ppm}$.

\subsection{4. [ $\mathrm{VO}$ (acac) $\left.\left\{\mathrm{Ph}-\mathrm{DAB}-\left(\mathrm{CH}_{2}\right)_{2} \mathrm{CH}_{3}\right\}\right] \mathrm{Cl}(\mathbf{3 b})$}

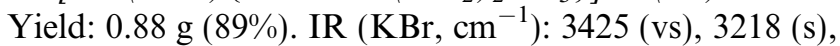
3068 (s), 2983 (w), 2938 (w), 1679 (vs), 1661 (vs), 1595 (s), 1529 (vs), 1451 (w), 1420 (w), $1212(\mathrm{~s}), 1175(\mathrm{w}), 1023(\mathrm{w})$, 998 (vs), 877 (m), 719 (s), 643 (s), 486 (m). ${ }^{1} \mathrm{H}$ NMR (400 MHz, $\mathrm{CDCl}_{3}$, r.t., TMS): $\delta=0.79-0.91$ (m, $6 \mathrm{H}$, $\left.\mathrm{CH}_{2} \mathrm{CH}_{3}\right), 1.19\left(\mathrm{~s}, 4 \mathrm{H}, \mathrm{CH}_{2} \mathrm{CH}_{2} \mathrm{CH}_{3}\right), 1.54\left(\mathrm{~s}, 12 \mathrm{H}, \mathrm{CH}_{3}\right.$ acac), 2.29 (s bd, $4 \mathrm{H}, \mathrm{NCH}_{2} ; 2 \mathrm{H}$, acac), 7.43-7.47 (m, 4H, Ph), 7.59 (t, 2H, Ph), 7.89-7.93 (m, 4H, Ph) ppm.

\subsection{Preparation of $M C M-41-L$ (4)}

A solution of $\mathrm{Ph}-\mathrm{DAB}-\left(\mathrm{CH}_{2}\right)_{3} \mathrm{Si}(\mathrm{OEt})_{3}(\mathbf{1 a}) \quad(0.70 \mathrm{~g}$, $1.13 \mathrm{mmol})$ in toluene $(10 \mathrm{~mL})$ was added to a suspension of MCM-41 $(0.8 \mathrm{~g})$ in toluene $(10 \mathrm{~mL})$ and the mixture heated at $373 \mathrm{~K}$ for $9 \mathrm{~h}$. The resultant solid was then filtered off and washed four times with $\mathrm{CH}_{2} \mathrm{Cl}_{2}(4 \times 15 \mathrm{~mL})$, and dried in vacuum at $323 \mathrm{~K}$ for $3 \mathrm{~h}$. Elemental analysis found: C, 11.09; N, 1.49; H, 2.71. IR $\left(\mathrm{KBr}, \mathrm{cm}^{-1}\right): 3065$ (w), $2978(\mathrm{~m}), 2932(\mathrm{w}), 1654(\mathrm{~m}), 1638(\mathrm{~m}), 1622(\mathrm{~m})$, 1600 (m), 1542 (vw), 1508 (m), 1496 (m), 1450 (m), 1394 (m), 1240 (vs), 1078 (vs), $798(\mathrm{~s}), 735$ (m), $700(\mathrm{~m}) \cdot{ }^{13} \mathrm{C}$ CP MAS NMR: $\delta=9.1\left(\mathrm{SiCH}_{2}\right), 16.5,20.8,23.9,42.8$, 58.0, 127.6 (phenyl-C) ppm. ${ }^{29} \mathrm{Si}$ MAS NMR: $\delta=-53.3$ (bd), $-108.6 \mathrm{ppm} .{ }^{29} \mathrm{Si}$ CP MAS NMR: $\delta=-54.3\left(\mathrm{~T}^{1}\right)$, $-59.5\left(\mathrm{~T}^{2}\right),-68.7\left(\mathrm{~T}^{3}\right),-103.1\left(\mathrm{sh}, \mathrm{Q}^{3}\right),-108.7\left(\mathrm{sh}, \mathrm{Q}^{4}\right)$ ppm.

\subsection{Preparation of $M C M-41 / M n(\text { acac })_{2}[P h-D A B-$ $\left.\left(\mathrm{CH}_{2}\right)_{3} \mathrm{Si}(\mathrm{OEt})_{3}\right](5)$}

A solution of $\left[\mathrm{Mn}(\mathrm{acac})_{2}\left\{\mathrm{Ph}-\mathrm{DAB}-\left(\mathrm{CH}_{2}\right)_{3} \mathrm{Si}(\mathrm{OEt})_{3}\right\}\right]$ (2a) $(0.66 \mathrm{~g}, 0.73 \mathrm{mmol})$ in methanol $(10 \mathrm{~mL})$ was added to a suspension of MCM-41 $(1.0 \mathrm{~g})$ in toluene $(10 \mathrm{~mL})$ and the mixture stirred at room temperature for $24 \mathrm{~h}$. The solution was then filtered and the pale powder is washed repeatedly with $\mathrm{CH}_{2} \mathrm{Cl}_{2}(4 \times 20 \mathrm{~mL})$, before drying in vacuum at room temperature for several hours. Elemental analysis found: $\mathrm{C}, 16.40 ; \mathrm{N}, 0.90 ; \mathrm{H}, 2.12 ; \mathrm{Mn}, 0.70$. IR $\left(\mathrm{KBr}, \mathrm{cm}^{-1}\right)$ : $2921(\mathrm{w}), 1605(\mathrm{~m}), 1539(\mathrm{~m}), 1494(\mathrm{~m}), 1452$ (m), 1368 (s), 1242 (vs), 1076 (vs), 948 (sh), 804 (s), 732 (m), $695(\mathrm{~m}) .{ }^{13} \mathrm{C}$ CP MAS NMR: $\delta=9.5,14.4,21.1,26.9,44.6$, 104.7, $127.1 \mathrm{ppm} .{ }^{29} \mathrm{Si}$ MAS NMR: $\delta=-50.5,-93.5\left(\mathrm{Q}^{2}\right)$, $-103.6\left(\mathrm{Q}^{3}\right),-108.8\left(\mathrm{Q}^{4}\right) \mathrm{ppm}$.

\subsection{Preparation of $M C M-41-L / M n(a c a c)_{2}\left(5^{\prime}\right)$}

A solution of $\left[\mathrm{Mn}(\mathrm{acac})_{3}\right](0.19 \mathrm{~g}, 0.55 \mathrm{mmol})$ in methanol $(5 \mathrm{~mL})$ was added to a suspension of MCM-41-L (4) $(0.8 \mathrm{~g})$ in toluene $(10 \mathrm{~mL})$ and in the presence of $\mathrm{HCl}$ $(0.1 \mathrm{~mL})$ and the resulting mixture was stirred overnight at $323 \mathrm{~K}$. The resultant solid was then filtered off and washed with $\mathrm{CH}_{2} \mathrm{Cl}_{2}(4 \times 20 \mathrm{~mL})$, and dried in vacuum at room temperature for $3 \mathrm{~h}$. Elemental analysis found: C, 16.8; N, 1.52; H, 2.30; $\mathrm{Mn}, 2.90$. IR $\left(\mathrm{KBr}, \mathrm{cm}^{-1}\right): 2930$ (vw), $1607(\mathrm{~m}), 1570(\mathrm{~m}), 1539(\mathrm{~m}), 1457(\mathrm{w}), 1362(\mathrm{~m})$, 1240 (vs), 1081 (vs), 936 (s), 807 (s), 696 (m). ${ }^{13} \mathrm{C} \mathrm{CP}$ MAS NMR: $\delta=10.2\left(\mathrm{SiCH}_{2}\right), 17.2,20.9,24.5,42.8$, 57.2, 106.9, 127.8 (phenyl-C), $190.7(\mathrm{C}=\mathrm{O}) .{ }^{29} \mathrm{Si}$ MAS NMR: $\delta=-21.9,-56.0$ (bd), -108.5 ppm. ${ }^{29} \mathrm{Si}$ CP MAS NMR: $\delta=-56.5\left(\mathrm{~T}^{1}\right),-59.1\left(\mathrm{~T}^{2}\right),-66.1\left(\mathrm{~T}^{3}\right),-108.9$ $\left(\mathrm{sh}, \mathrm{Q}^{4}\right) \mathrm{ppm}$.

\subsection{Preparation of $M C M-41 / V O(a c a c)[P h-D A B-$ $\left.\left(\mathrm{CH}_{2}\right)_{3} \mathrm{Si}(\mathrm{OEt})_{3}\right](\mathbf{6})$}

A solution of $\left[\mathrm{VO}(\mathrm{acac})\left\{\mathrm{Ph}-\mathrm{DAB}-\left(\mathrm{CH}_{2}\right)_{3} \mathrm{Si}(\mathrm{OEt})_{3}\right\}\right] \mathrm{Cl}$ (3a) $(0.77 \mathrm{~g}, 0.94 \mathrm{mmol})$ in methanol $(10 \mathrm{~mL})$ was added to a suspension of MCM-41 $(0.94 \mathrm{~g})$ in toluene $(10 \mathrm{~mL})$ and the mixture stirred at room temperature for $24 \mathrm{~h}$. The solution was then filtered and the pale powder is washed 
repeatedly with $\mathrm{CH}_{2} \mathrm{Cl}_{2}(4 \times 20 \mathrm{~mL})$, before drying in vacuum at room temperature for several hours. Elemental analysis found: $\mathrm{C}, 9.42 ; \mathrm{N}, 1.08 ; \mathrm{H}, 1.55 ; \mathrm{V}, 0.80$. IR $(\mathrm{KBr}$, $\mathrm{cm}^{-1}$ ): $3062(\mathrm{vw}), 2956(\mathrm{w}), 2925(\mathrm{w}), 1633(\mathrm{~m}), 1567(\mathrm{w})$, 1541(w), $1461(\mathrm{w}), 1366(\mathrm{w}), 1230(\mathrm{sh}), 1240$ (vs), 1083 (vs), 949 (sh), 806 (m), 734 (m), 698 (m), 576 (m). ${ }^{13} \mathrm{C} \mathrm{CP}$ MAS NMR: $\delta=11.0,16.5,21.9,23.8 .42 .5,56.8,102.7$, 128.7 (phenyl-C), $195.9(\mathrm{C}=\mathrm{O}) \mathrm{ppm} .{ }^{29} \mathrm{Si}$ MAS NMR: $\delta=-55.6(\mathrm{bd}),-95.1\left(\mathrm{Q}^{2}\right)-101.1\left(\mathrm{Q}^{3}\right),-108.2\left(\mathrm{Q}^{4}\right)$ ppm. ${ }^{29} \mathrm{Si}$ CP MAS NMR: $\delta=-55.0\left(\mathrm{~T}^{1}\right),-58.4\left(\mathrm{~T}^{2}\right)$, $-63.2\left(\mathrm{~T}^{3}\right),-92.4\left(\mathrm{Q}^{2}\right),-104.1\left(\mathrm{Q}^{3}\right),-108.5\left(\mathrm{Q}^{4}\right) \mathrm{ppm}$.

\subsection{Preparation of $M C M-41-L / V O($ acac $)\left(6^{\prime}\right)$}

A solution of $\left[\mathrm{VO}(\mathrm{acac})_{2}\right](0.18 \mathrm{~g}, 0.66 \mathrm{mmol})$ in methanol $(5 \mathrm{~mL})$ was added to a suspension of MCM-41-L (4) $(0.8 \mathrm{~g})$ in toluene $(10 \mathrm{~mL})$ and in the presence of $\mathrm{HCl}$ $(0.1 \mathrm{~mL})$ and the resulting mixture was stirred overnight at $323 \mathrm{~K}$. The resultant solid was then filtered off and washed with $\mathrm{CH}_{2} \mathrm{Cl}_{2}(4 \times 20 \mathrm{~mL})$, and dried in vacuum at room temperature for $3 \mathrm{~h}$. Elemental analysis found: C, 16.94; N, 1.24; H, 2.27; V, 2.40. IR $\left(\mathrm{KBr}, \mathrm{cm}^{-1}\right): 2930$ (vw), $1683(\mathrm{~m}), 1568(\mathrm{w}), 1538(\mathrm{w}), 1450(\mathrm{vw}), 1367(\mathrm{w})$, 1241 (vs), 1080 (vs), 936 (s), 800 (m), 733 (m), $696(\mathrm{~m})$. ${ }^{13} \mathrm{C}$ CP MAS NMR: $\delta=9.6\left(\mathrm{SiCH}_{2}\right), 21.0,25.8,42.8$, 58.3, 104.0, 127.9 (phenyl-C), $192.3(\mathrm{C}=\mathrm{O}) .{ }^{29} \mathrm{Si}$ MAS NMR: $\delta=-58.9(\mathrm{bd}),-109.1 \mathrm{ppm} .{ }^{29} \mathrm{Si}$ CP MAS NMR: $\delta=-50.6\left(\mathrm{~T}^{1}\right),-57.7\left(\mathrm{~T}^{2}\right),-67.5\left(\mathrm{~T}^{3}\right),-98.0,-106.0$, $-110.3\left(\mathrm{sh}, \mathrm{Q}^{4}\right) \mathrm{ppm}$.

\subsection{DFT calculations}

DFT [22] calculations were performed using the Gaussian 03 program, rev. B.04 [23]. Molecular structures based on Cambridge Structural Database (CSD) [24] related structures were fully optimised without any symmetry constraints at the unrestricted B3LYP [25] level with the lanl2dz basis set [26] on $\mathrm{Mn}$ and $\mathrm{V}$ atoms and $6-31 \mathrm{G}^{*}$ basis set [27] for all the remaining atoms. Frequency calculations were performed at the same level to confirm the nature (minima) of the stationary points determined.

\subsection{Magnetisation studies}

Magnetisation data were collected using a SQUID magnetometer (Quantum Design MPMS) over the temperature range from 2 to $200 \mathrm{~K}$, at applied magnetic fields up to $5.5 \mathrm{~T}$. Besides the paramagnetic signal due to $\mathrm{Mn}$ or $\mathrm{V}$ ions, a diamagnetic temperature independent contribution was detected in all samples. For each magnetisation versus temperature curve, collected at a certain magnetic field, the diamagnetic fraction was determined from the value of the intercept $B$ in the plot of the magnetic susceptibility $\chi$ versus inverse temperature $(\chi=C / T+B)$, in the temperature region where the Curie law is valid, and subtracted from the total magnetic signal. The paramagnetic data were then analysed using the spin-Hamiltonian model, providing information on the concentration of metallic ions, their spin, local symmetry and zero-field splitting parameters. Further details on data collection and fitting procedure can be found in [28].

\subsection{Catalytic studies}

The liquid phase catalytic oxidations were carried out at $328 \mathrm{~K}$ under air (atmospheric pressure) in a reaction vessel equipped with a magnetic stirrer and immersed in a thermostated oil bath. $175 \mathrm{mg} \mathrm{MCM}-41$-supported catalyst plus $7.2 \mathrm{mmol}$ cyclooctene (or 1\% molar ratio of free complex/substrate) and a substrate/oxidant molar ratio of 0.65 (tert-butyl hydroperoxide, $5.5 \mathrm{M}$ in decane) were used. The course of the reaction was monitored using a gas chromatograph (Varian 3800) equipped with a capillary column (SPB-5, $20 \mathrm{~m} \times 0.25 \mathrm{~mm}$ ) and a flame ionisation detector. The products were identified by gas chromatography-mass spectrometry (HP 5890 Series II GC; HP 5970 Series Mass Selective Detector) using $\mathrm{He}$ as carrier gas.

\section{Results and discussion}

\subsection{Synthesis and characterisation of the complexes}

The triethoxysilyl ligand $\mathrm{Ph}-\mathrm{DAB}-\left(\mathrm{CH}_{2}\right)_{3} \mathrm{Si}(\mathrm{OEt})_{3}$ (1a) was prepared by the reaction of benzil $\left[\mathrm{C}_{6} \mathrm{H}_{5}(\mathrm{CO})\right.$ (CO) $\mathrm{C}_{6} \mathrm{H}_{5}$ ] with two equivalents of (3-aminopropyl)triethoxysilane [14]. Each of the precursor complexes $\left[\mathrm{Mn}(\mathrm{acac})_{3}\right]$ and $\left[\mathrm{VO}(\mathrm{acac})_{2}\right]\left(\mathrm{acac}=\mathrm{C}_{5} \mathrm{H}_{7} \mathrm{O}_{2}^{-}\right)$was treated in methanol with one equivalent of $\mathbf{1 a}$, in the presence of $\mathrm{HCl}$, affording, in good yield, two complexes characterised as $\left[\mathrm{Mn}(\mathrm{acac})_{2}\left\{\mathrm{Ph}-\mathrm{DAB}-\left(\mathrm{CH}_{2}\right)_{3} \mathrm{Si}(\mathrm{OEt})_{3}\right\}\right]$ (2a) and $\left[\mathrm{VO}(\mathrm{acac})\left\{\mathrm{Ph}-\mathrm{DAB}-\left(\mathrm{CH}_{2}\right)_{3} \mathrm{Si}(\mathrm{OEt})_{3}\right\}\right] \mathrm{Cl}(\mathbf{3 a})$, (Scheme 1).

The FTIR spectra of compounds 2a and 3a are dominated by the strong absorptions of the $\mathrm{Si}(\mathrm{OEt})_{3}$ groups, which overlap with other relevant spectral features of the complexes. The coordination of 1,4-diazabutadiene ligand 1a to the metal centres is supported by the $v_{\mathrm{C}=\mathrm{N}}$ band observed for free 1a at $1674 \mathrm{~cm}^{-1}$ and shifted to 1685 and $1684 \mathrm{~cm}^{-1}$ for complexes $\mathbf{2 a}$ and $\mathbf{3 a}$, respectively. Strong bands assigned to the $v_{\mathrm{C}=\mathrm{O}}$ modes of the acac ligand appear at 1678 and $1660 \mathrm{~cm}^{-1}$ for complex $\mathbf{2 a}$, and at 1565 and $1522 \mathrm{~cm}^{-1}$ for complex 3a. Bands corresponding to the $v_{\mathrm{Si}-\mathrm{O}-\mathrm{Si}}$ are observed at $1066 \mathrm{~cm}^{-1}$ for complex 2a and at $1068 \mathrm{~cm}^{-1}$ for complex 3a, indicating some degree of polymerisation. The strong $v_{\mathrm{V}=\mathrm{O}}$ mode shifted from $995 \mathrm{~cm}^{-1}$ in the $\left[\mathrm{VO}(\mathrm{acac})_{2}\right]$ precursor to $998 \mathrm{~cm}^{-1}$ in complex 3a. The preparation of the analogous ligand $\mathrm{Ph}-\mathrm{DAB}-\left(\mathrm{CH}_{2}\right)_{2} \mathrm{CH}_{3}(\mathbf{1 b})$, with terminal methyl groups, instead of the bulky $\mathrm{Si}(\mathrm{OEt})_{3}$ required for surface binding to MCM-41 (Scheme 1), and their complexes $\left[\mathrm{Mn}(\mathrm{acac})_{2}\left\{\mathrm{Ph}-\mathrm{DAB}-\left(\mathrm{CH}_{2}\right)_{2} \mathrm{CH}_{3}\right\}\right](\mathbf{2 b})$ and $[\mathrm{VO}(\mathrm{acac})\{\mathrm{Ph}-$ DAB- $\left.\left.\left(\mathrm{CH}_{2}\right)_{2} \mathrm{CH}_{3}\right\}\right] \mathrm{Cl}(\mathbf{3 b})$, allowed a better spectroscopic analysis. The $v_{\mathrm{C}=\mathrm{O}}$ bands in $\mathbf{2 a}$ and $\mathbf{3 a}$, and $v_{\mathrm{V}=\mathrm{O}}$ in $\mathbf{3 a}$, appear in the same positions in $\mathbf{2} \mathbf{b}$ and $\mathbf{3 b}$, suggesting that 

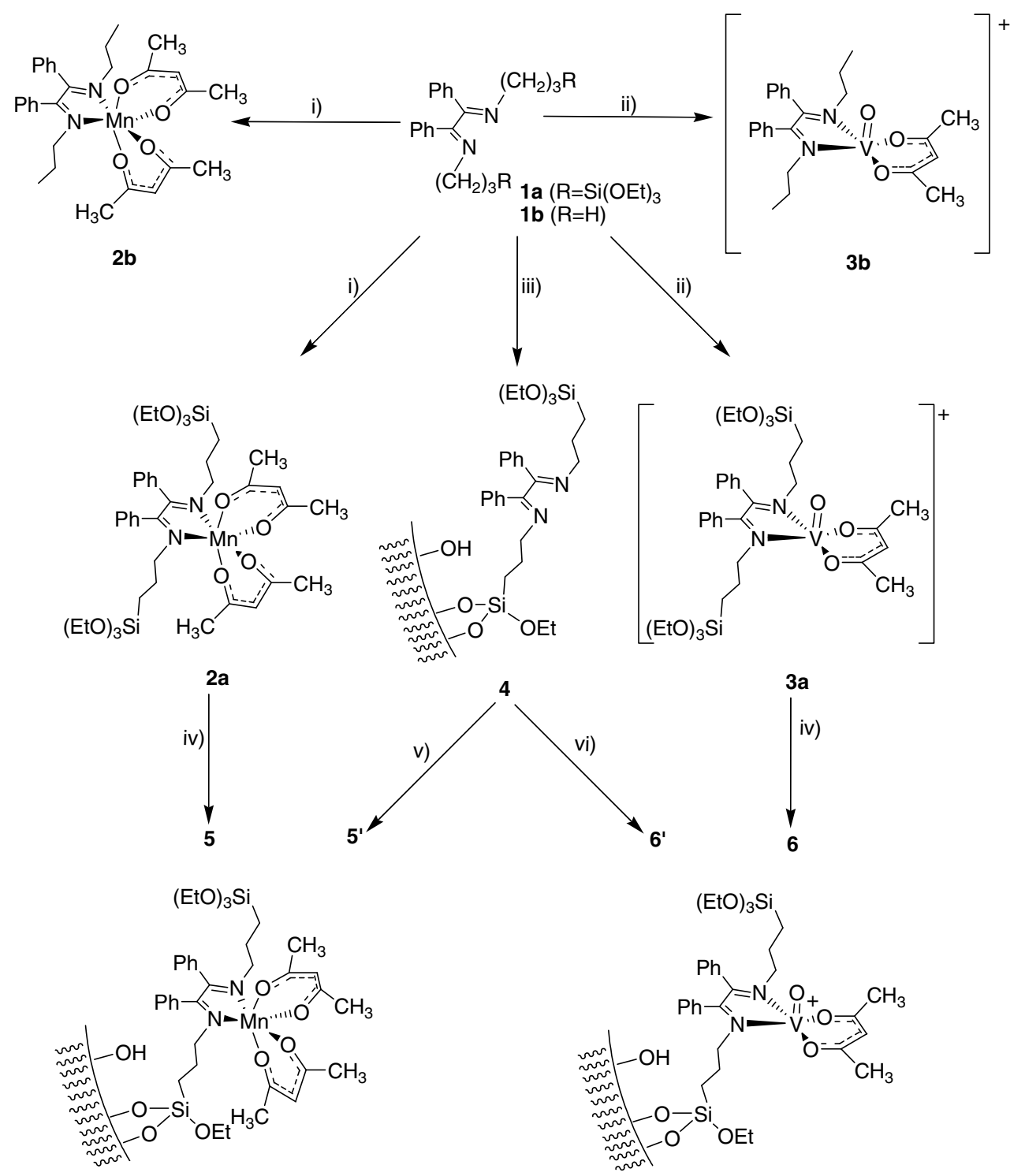

Scheme 1. Schematic overview of the synthetic procedures described in this work. Reagents: (i) $\mathrm{Mn}(\mathrm{acac})_{3}, \mathrm{MeOH}, \mathrm{HCl}$; (ii) $\mathrm{VO}(\mathrm{acac})_{2}, \mathrm{MeOH}, \mathrm{HCl}$; (iii) MCM-41, toluene; (iv) MCM-41, toluene, $\mathrm{MeOH}, \mathrm{HCl}$; (v) $\mathrm{Mn}(\mathrm{acac})_{3}$, toluene, $\mathrm{MeOH}, \mathrm{HCl}$; (vi) $\mathrm{VO}(\mathrm{acac})_{2}$, toluene, $\mathrm{MeOH}, \mathrm{HCl}$.

the ligand modification has not led to changes in the coordination environment of the metals.

On the other hand, the bands assigned to the $\beta_{\mathrm{C}-\mathrm{H}}$ modes are observed in the range $1600-1400 \mathrm{~cm}^{-1}$ for both $\mathbf{2 b}$ and $\mathbf{3 b} ; v_{\mathrm{Mn}-\mathrm{N}}$ and $v_{\mathrm{Mn}-\mathrm{O}}$ modes are observed at 719 and $643 \mathrm{~cm}^{-1}$ for complex $\mathbf{2 b}$, while complex $\mathbf{3 b}$ exhibits the $v_{\mathrm{C}-\mathrm{N}}$ mode at $1023 \mathrm{~cm}^{-1}$, the $v_{\mathrm{V}-\mathrm{N}}$ modes at $719 \mathrm{~cm}^{-1}$ and $643 \mathrm{~cm}^{-1}$, and $v_{\mathrm{V}-\mathrm{O}}$ mode at $486 \mathrm{~cm}^{-1}$.

The ${ }^{1} \mathrm{H}$ and ${ }^{13} \mathrm{C}$ NMR spectra of $\mathrm{Ph}-\mathrm{DAB}-$ $\left(\mathrm{CH}_{2}\right)_{3} \mathrm{Si}(\mathrm{OEt})_{3}$ (1a) agree with those reported [14]. The ${ }^{1} \mathrm{H}$ NMR spectra of complexes $\mathbf{2 a}$ and $\mathbf{3 a}$ consist of broad signals, consistent with the presence of paramagnetic species, namely $\mathrm{V}(\mathrm{IV}) \mathrm{d}^{1}$ and $\mathrm{Mn}(\mathrm{II}) \mathrm{d}^{5}$, and are therefore considerably noisy. It was impossible to collect their ${ }^{13} \mathrm{C}$ NMR spectra. The ${ }^{1} \mathrm{H}$ NMR spectra of both complexes $\mathbf{2 a}$ and $\mathbf{3 a}$ display the signals characteristic of the coordinated ligand 1a, slightly shifted (Table 1). The $\mathrm{CH}_{3}$ of the ethyl group is shifted to low field, while the signals of all the other protons in complexes $\mathbf{2 a}$ and $\mathbf{3 a}$ are shifted upfield; there are two signals, assigned to the protons of the acac ligands, at 1.85 and 3.05 ppm (2a) or 2.70 and 4.65 (3a).

A search in the Cambridge Structural Database [24] did not provide any structures of $\mathrm{V}$ (IV) and $\mathrm{Mn}$ (II) that could be directly compared with those of $\mathbf{2} \mathbf{b}$ and $\mathbf{3 b}$ (or $\mathbf{2 a}$ and 3a), and no crystals suitable for a structure determination could be obtained. Therefore, unrestricted DFT calculations [22] were carried out on complexes $\mathbf{2 b}$ and $\mathbf{3 b}$, using the G03 package [23] at the B3LYP [25] level. The reliability of the computational approach was mainly checked by comparing the calculated vibrational spectra, since there is no structure available with exactly the same coordination sphere around V or Mn. For this comparison, complexes of ligand $\mathbf{1 b}$ were prepared. The calculated structures are shown in Fig. 1. 
Table 1

Chemical shifts for the protons of ligand $\mathbf{1 a}$ and complexes $\mathbf{2 a}$ and $\mathbf{3 a}(\delta / \mathrm{ppm})$

\begin{tabular}{|c|c|c|c|c|c|c|c|}
\hline Compound & $\mathrm{OCH}_{2} \mathrm{CH}_{3}$ & $\mathrm{OCH}_{2} \mathrm{CH}_{3}$ & $\mathrm{CH}_{2} \mathrm{Si}$ & $\mathrm{CH}_{2} \mathrm{CH}_{2} \mathrm{CH}_{2}$ & $\mathrm{~N}-\mathrm{CH}_{2}$ & $\mathrm{Ph}$ & acac \\
\hline & & & & & & $7.32-7.50$ & \\
\hline \multirow[t]{3}{*}{$1 \mathbf{a}$} & $1.15-1.24$ & $3.73-3.84$ & $0.6-0.68$ & $1.76-1.86$ & $3.4-3.44$ & $7.57-7.75$ & - \\
\hline & & & & & & $7.88-7.93$ & \\
\hline & & & & & & $7.01-7.27$ & 1.85 \\
\hline \multirow[t]{3}{*}{$2 \mathbf{a}$} & 1.38 & 3.05 & 0.75 & 1.60 & 3.05 & 7.51 & \\
\hline & & & & & & & 3.05 \\
\hline & & & & & & 7.20 & \\
\hline \multirow[t]{2}{*}{$3 \mathbf{a}$} & 1.60 & 4.65 & 0.55 & 1.60 & 3.10 & 7.40 & 2.70 \\
\hline & & & & & & 7.80 & \\
\hline
\end{tabular}
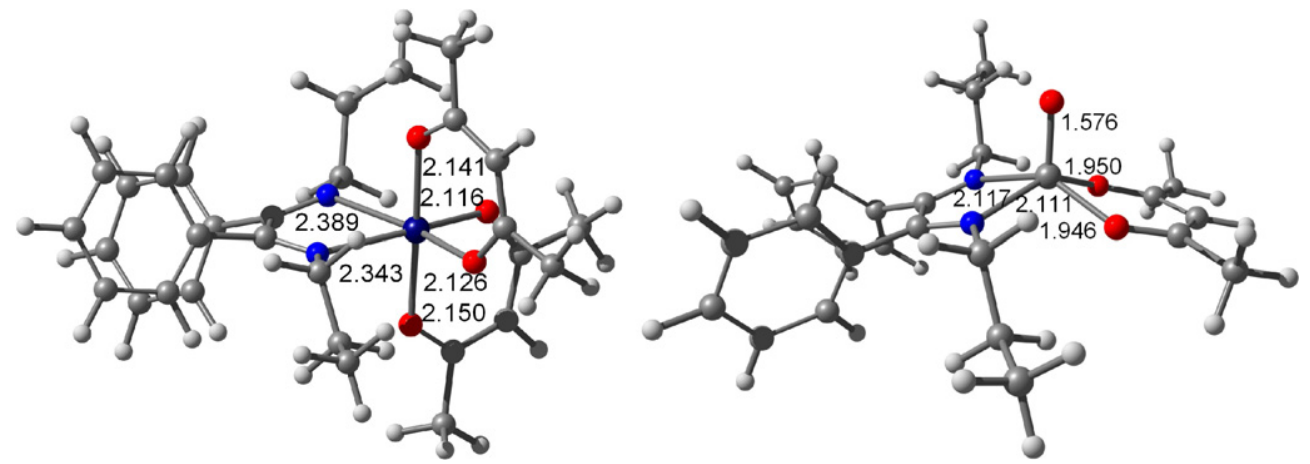

Fig. 1. DFT optimised geometries of complexes $\left[\mathrm{Mn}(\mathrm{acac})_{2}\left\{\mathrm{Ph}-\mathrm{DAB}-\left(\mathrm{CH}_{2}\right)_{2} \mathrm{CH}_{3}\right\}\right](\mathbf{2 b})$ (left) and $\left[\mathrm{VO}(\mathrm{acac})\left\{\mathrm{Ph}-\mathrm{DAB}-(\mathrm{CH})_{2} \mathrm{CH}\right\}\right]^{+}(\mathbf{3 b})($ right $)$, showing some relevant distances.

In $\left[\mathrm{Mn}(\mathrm{acac})_{2}\left\{\mathrm{Ph}-\mathrm{DAB}-\left(\mathrm{CH}_{2}\right)_{2} \mathrm{CH}_{3}\right\}\right](\mathbf{2 b})$, the formal oxidation state of $\mathrm{Mn}$ is II, so that two different spin states are possible, the high spin state $\mathrm{S}=5 / 2$ being more stable by $17 \mathrm{kcal} \mathrm{mol}^{-1}$. The octahedral coordination around $\mathrm{Mn}(\mathrm{II})$ is distorted by the non equivalence of the ligands, with an $\mathrm{O}-\mathrm{Mn}-\mathrm{O}$ angle of $176^{\circ}$, and two $\mathrm{N}-\mathrm{Mo}-\mathrm{O}-\mathrm{O}$ angles of $164^{\circ}$ and $162^{\circ}$. The two $\mathrm{Mn}-\mathrm{O}$ distances to the $\mathrm{O}$ trans to the nitrogen donors ( 2.116 and $2.126 \AA$ ) are comparable to 2.117 and $2.124 \AA$ determined in $[\mathrm{Mn}(\mathrm{acac})$ (phen) $)_{2}$, the closest $\mathrm{Mn}$ (II) complex found, where the acac ligand is also trans to a nitrogen ligand (phen). The other two $\mathrm{Mn}-\mathrm{O}$ distances are longer $(2.141$ and $2.150 \AA)$. The $\mathrm{Mn}-\mathrm{N}$ distances (2.343 and $2.389 \AA$ ) are slightly longer than the corresponding distances of 2.279 and $2.321 \AA$ in $\left[\mathrm{Mn}(\mathrm{acac})(\mathrm{phen})_{2}\right]$.

The V(IV) complexes bearing acac and dinitrogen ligands available in the CSD are hexacoordinate, which makes comparison trickier, but the $\mathrm{V}=\mathrm{O}$ bond is similar to that found in the structures with REFCODEs XACPLV01, KOBKUH, and KACROV (1.622, 1.588, $1.597 \AA$ ). In these complexes, the $\mathrm{V}-\mathrm{N}$ bonds range from 2.055 to $2.194 \AA$, very close to 2.111 and $2.117 \AA$ calculated for $\left[\mathrm{VO}(\mathrm{acac})\left\{\mathrm{Ph}-\mathrm{DAB}-\left(\mathrm{CH}_{2}\right)_{2} \mathrm{CH}_{3}\right\}\right] \mathrm{Cl}(\mathbf{3 b})$, and $\mathrm{V}-\mathrm{O}$ bonds between 1.971 and $1.989 \AA$, compared to 1.946 and $1.950 \AA$ in $\mathbf{3 b}$. For comparison, calculations were also performed on the hexacoordinate $[\mathrm{VO}(\mathrm{acac})\{\mathrm{Ph}-\mathrm{DAB}-$ $\left.\left.\left(\mathrm{CH}_{2}\right)_{2} \mathrm{CH}_{3}\right\} \mathrm{Cl}\right]$ complex, where vanadium displays a distorted octahedral coordination. The $\mathrm{V}=\mathrm{O}$ lengthens very slightly to $1.598 \AA$, the same happening with the $\mathrm{V}-\mathrm{O}$ $(1.982$ and $1.977 \AA)$ and $\mathrm{V}-\mathrm{N}(2.143$ and $2.147 \AA)$ distances. These bonds lengths are closer to those of the $\mathrm{V}(\mathrm{IV})$ complexes used for comparison. Finally, the $\mathrm{V}-\mathrm{Cl}$ distance is $2.594 \AA$, indicating a weak bond.

The more characteristic modes, $v_{\mathrm{C}=\mathrm{N}}$ and $v_{\mathrm{C}=\mathrm{O}}$, in the vibrational spectra of $\mathbf{2 b}$ are calculated to appear at $1664 \mathrm{~cm}^{-1}$ and $1666 \mathrm{~cm}^{-1}$, for the first, and $1650 \mathrm{~cm}^{-1}$ for the later, very close to the observed frequencies of $1680 \mathrm{~cm}^{-1}\left(v_{\mathrm{C}=\mathrm{N}}\right)$, and $1661 \mathrm{~cm}^{-1}\left(v_{\mathrm{C}=\mathrm{O}}\right)$, supporting the formulation proposed for the complex.

The same vibrational modes are calculated for complex 3b at $1681 \mathrm{~cm}^{-1}, 1637 \mathrm{~cm}^{-1}\left(v_{\mathrm{C}=\mathrm{N}}\right)$ and $1608 \mathrm{~cm}^{-1}\left(v_{\mathrm{C}=\mathrm{O}}\right)$, which compare with experimental data at $1679 \mathrm{~cm}^{-1}$ $\left(v_{\mathrm{C}=\mathrm{N}}\right)$ and $1661 \mathrm{~cm}^{-1}\left(v_{\mathrm{C}=\mathrm{O}}\right)$. Of relevance is also the $v_{\mathrm{V}=\mathrm{O}}$ mode in $\mathbf{3 b}$ predicted at $1109 \mathrm{~cm}^{-1}$ being observed at $998 \mathrm{~cm}^{-1}$. In $\left[\mathrm{VO}(\mathrm{acac})\left\{\mathrm{Ph}-\mathrm{DAB}-\left(\mathrm{CH}_{2}\right)_{2} \mathrm{CH}_{3}\right\}\right] \mathrm{Cl}$ (3b), the $v_{\mathrm{C}=\mathrm{N}}$ mode is calculated at $1646 \mathrm{~cm}^{-1}$ and the $v_{\mathrm{C}=\mathrm{O}}$ mode at $1640 \mathrm{~cm}^{-1}$.

\subsection{Synthesis and characterisation of the functionalised materials}

The functionalised materials containing supported complexes were prepared from MCM-41 materials using two different strategies as depicted in Scheme 1.

In the first approach (grafting), treatment of MCM-41 with a solution of $\left[\mathrm{Mn}(\mathrm{acac})_{2}\left\{\mathrm{Ph}-\mathrm{DAB}-\left(\mathrm{CH}_{2}\right)_{3} \mathrm{Si}(\mathrm{OEt})_{3}\right\}\right]$ 
(2a) in toluene gave $\mathrm{MCM}-41 / \mathrm{Mn}(\mathrm{acac})_{2}[\mathrm{Ph}-\mathrm{DAB}-$ $\left.\left(\mathrm{CH}_{2}\right)_{3} \mathrm{Si}(\mathrm{OEt})_{3}\right]$ (5) containing approximately $0.7 \mathrm{wt} \%$ $\mathrm{Mn}\left(0.12 \mathrm{mmol} \mathrm{Mn} \cdot \mathrm{g}^{-1}\right)$. A similar procedure afforded the oxovanadium material MCM-41/VO(acac) $[\mathrm{Ph}-\mathrm{DAB}-$ $\left.\left(\mathrm{CH}_{2}\right)_{3} \mathrm{Si}(\mathrm{OEt})_{3}\right]$ (6), by incorporating $[\mathrm{VO}(\mathrm{acac})\{\mathrm{Ph}-$ $\left.\left.\mathrm{DAB}-\left(\mathrm{CH}_{2}\right)_{3} \mathrm{Si}(\mathrm{OEt})_{3}\right\}\right] \mathrm{Cl}(\mathbf{3 a})$ inside the pores of MCM41 , and led to a content of approximately $0.8 \mathrm{wt} \% \mathrm{~V}$ $\left(0.17 \mathrm{mmol} \mathrm{V} \cdot \mathrm{g}^{-1}\right)$.

The second approach consisted of a stepwise construction of the final materials MCM-41-L/Mn(acac $)_{2}\left(5^{\prime}\right)$ and MCM-41-L/VO(acac) $\left(\mathbf{6}^{\prime}\right)$ by a tethering procedure (Scheme 1). The MCM-41 host material was first treated with a toluene solution of $\mathrm{Ph}-\mathrm{DAB}-\left(\mathrm{CH}_{2}\right)_{3} \mathrm{Si}(\mathrm{OEt})_{3}(\mathbf{1 a})$ under reflux for $9 \mathrm{~h}$, leading to the derivatised material MCM-41-L (4). The precursor complexes [Mn(acac $\left.)_{3}\right]$ and $\left[\mathrm{VO}(\mathrm{acac})_{2}\right]$ were subsequently introduced by pore volume impregnation of toluene/methanol solutions, in the presence of $\mathrm{HCl}$, to give $\mathbf{5}^{\prime}$, with approximately $2.9 \mathrm{wt} \%$ $\mathrm{Mn}\left(0.52 \mathrm{mmol} \mathrm{Mn} \cdot \mathrm{g}^{-1}\right)$, and $\mathbf{6}^{\prime}$, with approximately $2.4 \mathrm{wt} \% \mathrm{~V}\left(0.46 \mathrm{mmol} \mathrm{V} \cdot \mathrm{g}^{-1}\right)$, as indicated by elemental analysis.

The powder XRD patterns of the pristine calcined MCM-41 starting material agree with reported patterns, indicating well-ordered materials (Fig. 2) [3,4,29]. Several distinct Bragg peaks are observed in the range $2 \theta=2-8^{\circ}$, which can be indexed to $h k l$ reflections for a hexagonal unit cell (using the strongest reflection, $d_{100}, a=2 d_{100} /$ $\sqrt{ } 3=34.0 \AA$ ). Direct grafting of complexes 2a and 3a resulted in a reduction of the intensity of the diffraction peaks in materials $\mathbf{5}$ and $\mathbf{6}$, but several distinct Bragg peaks are still observed, indicating retention of the long-range hexagonal symmetry. The attenuation of the peak intensities should not be interpreted as a loss of order, but to a likely reduction in the X-ray scattering contrast between the silica walls and pore-filling material [30]. On the other hand, grafting of the MCM-41 host material with the triethoxysilyl ligand 1a results in a strong reduction of the intensity of the X-ray diffractions (Fig. 2). Reaction of the MCM-41-L (4) with the complexes $\left[\mathrm{Mn}(\mathrm{acac})_{3}\right]$ or $\left[\mathrm{VO}(\mathrm{acac})_{2}\right]$ further reduces the intensity of the peaks. The tethering method allows an introduction of a very high content of diazabutadiene ligand, with a consequent reduction of the scattering contrast, and the loading of the metal complexes leads to a further decrease. The peak intensity reduction is less significant in $\mathbf{5}$ and $\mathbf{6}$ than in $\mathbf{5}^{\prime}$ and $\mathbf{6}^{\prime}$ because of the lower ligand and metals contents in the first two. The material $\mathbf{5}$ is prepared by pore volume impregnation of the metal complex bearing the diazabutadiene ligand. The complex is far bulkier than ligand 1a and thus may have increased difficulty towards diffusion inside the material pores. The resulting material has thus a much smaller amount of metal than material $\mathbf{5}^{\prime}$, which was prepared by a stepwise approach. Similar results were found for materials $\mathbf{6}$ and $\mathbf{6}^{\prime}$.

The FTIR spectra of the parent host material MCM-41 is similar to that of other mesoporous silicious matrices. The bands at $1235 \mathrm{~cm}^{-1}$ and $1087 \mathrm{~cm}^{-1}$ are assigned to

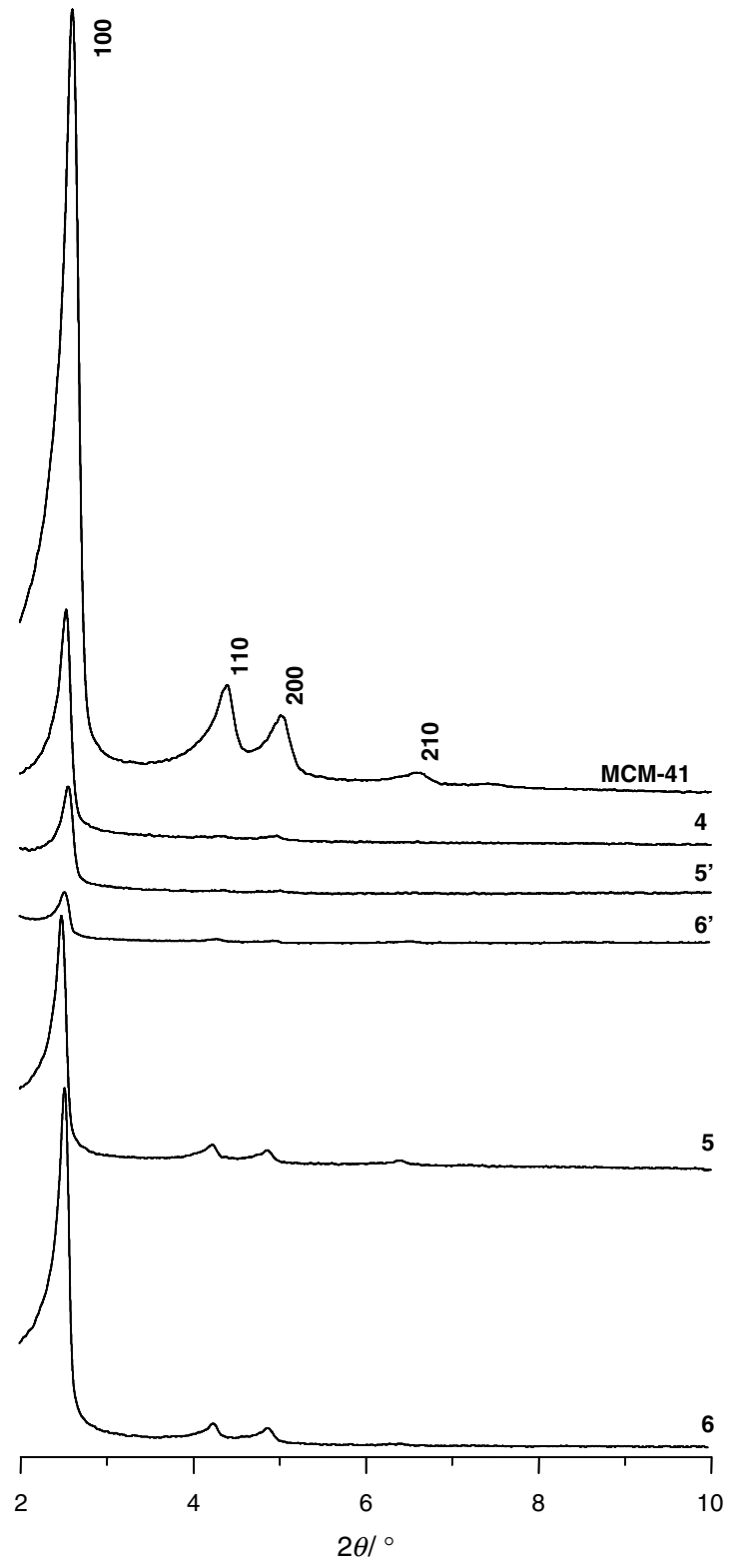

Fig. 2. Powder XRD patterns of MCM-41, MCM-41-L (4), MCM-41-L/ $\mathrm{Mn}(\mathrm{acac})_{2} \quad\left(5^{\prime}\right), \quad \mathrm{MCM}-41-\mathrm{L} / \mathrm{VO}(\mathrm{acac}) \quad\left(\mathbf{6}^{\prime}\right), \mathrm{MCM}-41 / \mathrm{Mn}(\mathrm{acac})_{2}[\mathrm{Ph}-$ $\left.\mathrm{DAB}-\left(\mathrm{CH}_{2}\right)_{3} \mathrm{Si}(\mathrm{OEt})_{3}\right]$ (5), and MCM-41/VO(acac)[Ph-DAB$\left.\left(\mathrm{CH}_{2}\right)_{3} \mathrm{Si}(\mathrm{OEt})_{3}\right](6)$.

the $v_{\text {asymSi-O-Si }}$ mode of the framework, with the corresponding $v_{\text {sym }}$ mode appearing at ca. $800 \mathrm{~cm}^{-1}$. An absorption at $963 \mathrm{~cm}^{-1}$ is assigned to a $\delta_{\mathrm{Si}-\mathrm{O}}$ mode of the $\mathrm{Si}-\mathrm{OH}$ groups. The treatment of the MCM with ligand 1a led to derivatised material MCM-41-L (4), which exhibits bands at $3090,2980,2950$ and $2920 \mathrm{~cm}^{-1}$, assigned to $v_{\mathrm{C}-\mathrm{H}}$ modes of the ligand, and the band at $1678 \mathrm{~cm}^{-1}$ to the $v_{\mathrm{C}=\mathrm{N}}$ mode of the ligand. This result suggests that the ligand is indeed immobilised inside the pores of the host material, as previously described $[14,19]$. In material $\mathbf{4}$, it is still possible to assign a very strong band at $1090 \mathrm{~cm}^{-1}$ to the $v_{\text {asymSi-O-Si }}$ mode of the framework, the corresponding $v_{\mathrm{sym}}$ mode appearing at ca. $817 \mathrm{~cm}^{-1}$. 
Reaction of 4 with the precursor complexes $\left[\mathrm{Mn}(\mathrm{acac})_{3}\right]$ and $\left[\mathrm{VO}(\mathrm{acac})_{2}\right]$ led to the new materials $\mathbf{5}^{\prime}$ and $\mathbf{6}^{\prime}$, respectively. It is possible to assign, in the FTIR spectrum of the Mn-containing material $\mathbf{5}^{\prime}$, the band due to the $v_{\mathrm{C}=\mathrm{N}}$ mode of the ligand 1a at $1675 \mathrm{~cm}^{-1}$, as well as the three bands at $1624\left(v_{\mathrm{C}=\mathrm{O}}\right), 1567\left(\beta_{\mathrm{C}-\mathrm{H}}\right)$ and $1538 \mathrm{~cm}^{-1}\left(v_{\mathrm{C}=\mathrm{C}}\right)$ associated with the acac ligand (not shown). The corresponding bands are observed, for material $\mathbf{6}^{\prime}$, at $1683 \mathrm{~cm}^{-1}\left(v_{\mathrm{C}=\mathrm{N}}\right)$ and $1653\left(v_{\mathrm{C}=\mathrm{O}}\right), 1623\left(\beta_{\mathrm{C}-\mathrm{H}}\right)$ and $1559 \mathrm{~cm}^{-1}\left(v_{\mathrm{C}=\mathrm{C}}\right)$ for 1a and the acac ligand, respectively. The $v_{\text {asym }}$ mode of the $\mathrm{Si}-\mathrm{O}-\mathrm{Si}$ vibration appears at $1078 \mathrm{~cm}^{-1}$ in $\mathbf{5}^{\prime}$ and $1062 \mathrm{~cm}^{-1}$ in $\mathbf{6}^{\prime}$, and the $v_{\text {sym }}$ mode at 809 and $804 \mathrm{~cm}^{-1}$. The $v_{\mathrm{V}=\mathrm{O}}$ is expected to appear at ca. $998 \mathrm{~cm}^{-1}$ for material $\mathbf{6}^{\prime}$, as described above for complexes $\mathbf{3 a}$ and $\mathbf{3 b}$. Indeed, there is a small shoulder at this position, but given its weakness, compared with the intensity of the $v_{\text {asymSi-O-Si }}$ mode of the framework, the identification remains ambiguous.

For the two materials 5 and $\mathbf{6}$, the lower amounts of complex combined with the strong bands of the silica framework prevents a detailed assignment of the vibrational spectra, compared to materials $\mathbf{5}^{\prime}$ and $\mathbf{6}^{\prime}$. The $v_{\mathrm{C}=\mathrm{N}}$ of the ligand $1 \mathrm{a}$ is observed at $1678 \mathrm{~cm}^{-1}$ and $1682 \mathrm{~cm}^{-1}$ in materials $\mathbf{5}$ and $\mathbf{6}$, while the band assigned to the $v_{\mathrm{C}=\mathrm{O}}$ mode of the acac ligand appears at 1630 and $1628 \mathrm{~cm}^{-1}$ for $\mathbf{5}$ or $\mathbf{6}$, respectively. The $v_{\text {asym }}$ mode of the framework $\mathrm{Si}-\mathrm{O}-\mathrm{Si}$ units appears at the same positions as those found for the $\mathbf{5}^{\prime}$ and $\mathbf{6}^{\prime}$ materials. Nevertheless, the presence of the most characteristic bands of the two ligands $\left(v_{\mathrm{C}=\mathrm{O}}\right.$ and $v_{\mathrm{C}=\mathrm{N}}$, for $\mathbf{1 a}$ and acac) support the coordination of the metal complexes to the pendant ligands 1a bound to the surface.

Thermogravimetric analyses of the materials $5,5^{\prime}, \mathbf{6}, \mathbf{6}^{\prime}$, and MCM-41-L (4) were carried out. Excluding the mass losses due to water up to ca. $393 \mathrm{~K}$, materials $\mathbf{5}$ and $\mathbf{6}$ show smaller mass losses (15\% and $16 \%$, respectively), than those found for materials $\mathbf{5}^{\prime}$ and $\mathbf{6}^{\prime}$ (30\% and $28 \%$, respectively) above $393 \mathrm{~K}$. As expected, this is in good agreement with results from elemental analysis since the later materials were found to have higher ligand and metal loadings than the former. In addition, materials $\mathbf{5}^{\prime}$ and $\mathbf{6}^{\prime}$, prepared by the tethering approach, show higher mass losses than material 4 (mass loss of $20 \%$ above $393 \mathrm{~K}$ ). This is indicative that the metallic fragments were successfully introduced inside the mesopores with the formation of the immobilised complexes as shown in Scheme 1.

The MCM-41 starting material showed type IV $\mathrm{N}_{2}$ adsorption isotherm, typical of mesoporous solids, according to IUPAC classification [31]. The specific surface area $\left(S_{\mathrm{BET}}\right)$ and total pore volume $\left(V_{\mathrm{P}}\right)$ of pristine MCM-41 are $1046 \mathrm{~m}^{2} \mathrm{~g}^{-1}$ and $0.87 \mathrm{~cm}^{3} \mathrm{~g}^{-1}$, respectively (Table 2), and were calculated according with literature data $[29,32]$. Similar results were obtained for the V-containing materials $\left(\mathbf{6}\right.$ and $\left.\mathbf{6}^{\prime}\right)$. The isotherms of the modified materials obtained by grafting ( 5 and 6 ) showed a lower $\mathrm{N}_{2}$ uptake, pointing to a decrease in the specific surface area $(28 \%$ for 5 and $22 \%$ for material $\mathbf{6}$ ). The height of the capillary condensation step and the $p / p^{0}$ coordinate of the inflection
Table 2

Texture parameters taken from $\mathrm{N}_{2}$ adsorption data collected at $77 \mathrm{~K}$

\begin{tabular}{lllll}
\hline Sample & $S_{\text {BET }}\left(\mathrm{m}^{2} \mathrm{~g}^{-1}\right)^{\mathrm{a}}$ & $\Delta S_{\text {BET }}(\%)^{\mathrm{a}}$ & $V_{\mathrm{p}}\left(\mathrm{cm}^{3} \mathrm{~g}^{-1}\right)$ & $\Delta V_{\mathrm{p}}(\%)^{\mathrm{b}}$ \\
\hline MCM-41 & 1046 & - & 0.87 & - \\
$\mathbf{5}$ & 744 & -28 & 0.46 & -47 \\
$\mathbf{6}$ & 821 & -22 & 0.45 & -48 \\
$\mathbf{4}$ & 446 & -57 & 0.28 & -68 \\
$\mathbf{5}^{\prime}$ & 199 & -81 & 0.14 & -83 \\
$\mathbf{6}^{\prime}$ & 211 & -79 & 0.16 & -82 \\
\hline
\end{tabular}

${ }^{\text {a }}$ Variation of surface area in relation to parent MCM-41 material.

${ }^{\mathrm{b}}$ Variation of total pore volume in relation to parent MCM-41 material.

point decreased significantly, indicating changes in the pore size distribution, owing to grafting of the internal surface of MCM-41 with the manganese and oxovanadium species, 2a and 3a, respectively. These effects are even more pronounced in the solids prepared by tethering. Reduction in the $S_{\mathrm{BET}}$ and $V_{\mathrm{P}}$ of $57 \%$ and $68 \%$, respectively, are already observed after grafting of the ligand 1a, and $S_{\mathrm{BET}}$ and $V_{\mathrm{P}}$ further decreased after the inclusion of the metal complexes. In the case of $\mathbf{5}^{\prime}$ and $\mathbf{6}^{\prime}, S_{\mathrm{BET}}$ and $V_{\mathrm{P}}$ decreased ca. $80 \%$ relative to the parent MCM-41 material (Table 2). These results, together with the powder XRD results,

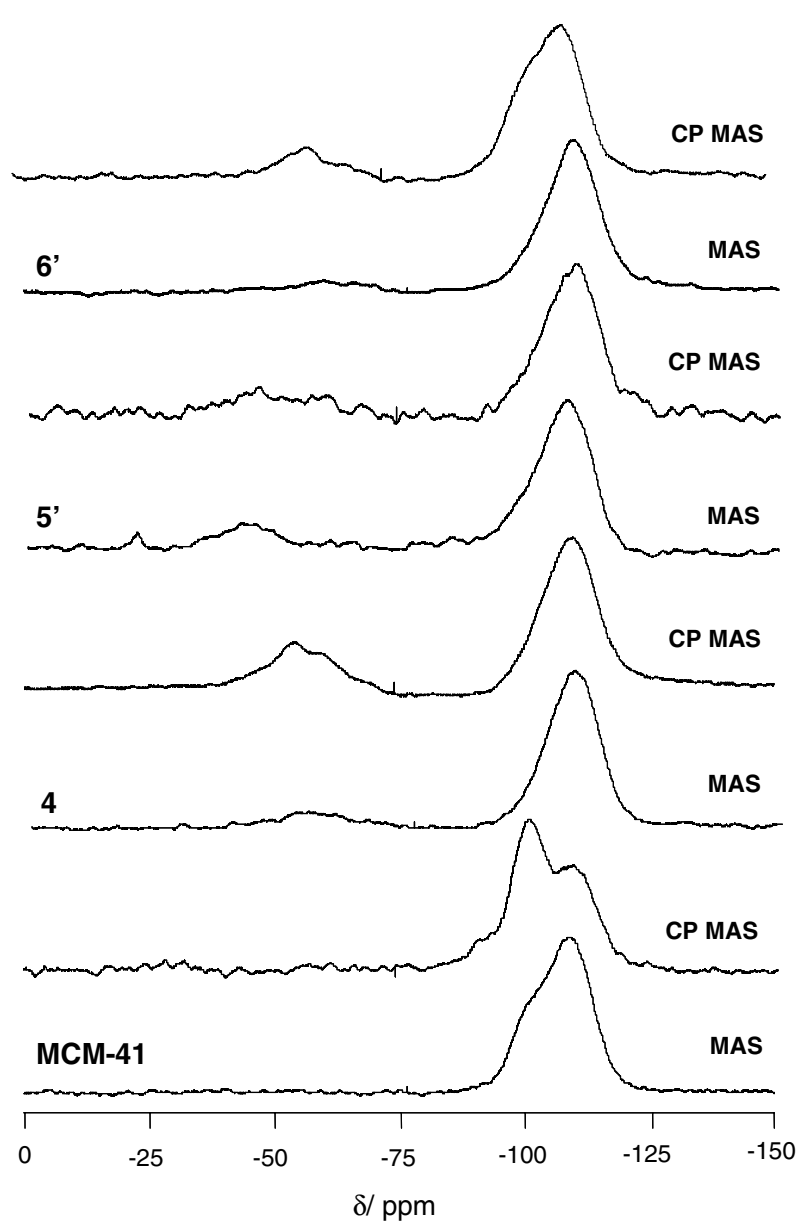

Fig. 3. ${ }^{29} \mathrm{Si}$ MAS and CP MAS NMR spectra of MCM-41, MCM-41-L (4), MCM-41-L/Mn(acac $)_{2}\left(5^{\prime}\right)$, and MCM-41-L/VO(acac) $\left(\mathbf{6}^{\prime}\right)$. 
suggest that the complexes were successfully supported on the internal surfaces of the mesoporous silica hosts.

Fig. 3 shows the ${ }^{29} \mathrm{Si}$ MAS and CP MAS NMR spectra for pristine calcined MCM-41, the MCM-41-L (4), and the derivatised materials $\mathbf{5}^{\prime}$ and $\mathbf{6}^{\prime}$. Unmodified MCM-41 displays two broad convoluted resonances in the ${ }^{29} \mathrm{Si} \mathrm{CP}$ MAS NMR spectrum at -109.2 and $-100.8 \mathrm{ppm}$, assigned, respectively, to $\mathrm{Q}^{4}$ and $\mathrm{Q}^{3}$ species of the silica framework $\left[\mathrm{Q}^{n}=\operatorname{Si}(\mathrm{OSi})_{n}(\mathrm{OH})_{4-n}\right]$. A weak shoulder is also observed at $\delta=-93.8$ for the $\mathrm{Q}^{2}$ species. The $\mathrm{Q}^{3}$ sites are associated with the single silanols $\mathrm{Si}-\mathrm{OH}$ (including hydrogen-bonded silanols), and the $\mathrm{Q}^{2}$ sites correspond to the geminal silanols. Grafting of the triethoxysilane ligand $\mathrm{Ph}-\mathrm{DAB}-\left(\mathrm{CH}_{2}\right)_{3} \mathrm{Si}(\mathrm{OEt})_{3}(\mathbf{1 a})$ into MCM-41 reduces the $\mathrm{Q}^{3}$ and $\mathrm{Q}^{2}$ resonances owing to the silylation of the surface and, concomitantly, increases the $\mathrm{Q}^{4}$ resonance. This is consistent with esterification of the isolated silanol groups by nucleophilic substitution at the silicon atom in the organic compounds. The ${ }^{29} \mathrm{Si} \mathrm{CP}$ MAS NMR spectrum of 4 display two signals at $\delta=-54.8$, $-59.4 \mathrm{ppm}$ and a weak, broad signal at $\delta=-69.0 \mathrm{ppm}$, assigned to $\mathrm{T}^{1}, \mathrm{~T}^{2}$ and $\mathrm{T}^{3}$ organosilica species $\left[\mathrm{T}^{m}=\mathrm{RSi}(\mathrm{OSi})_{m}(\mathrm{OH})_{3-m}\right]$, respectively, whereas the Q species only present a peak at $-108.3 \mathrm{ppm}$.

The ${ }^{29}$ Si MAS and CP MAS NMR spectra (Fig. 3) present a significant decrease of the signal to noise ratio. These observations can be related with the presence of paramagnetic nuclei in the materials. The ${ }^{29} \mathrm{Si}$ NMR spectra for materials 5 and $\mathbf{6}$ are similar to those of $\mathbf{5}^{\prime}$ and $\mathbf{6}^{\prime}$. These results show that for both post-synthesis modification techniques, the organosilanes reacted covalently with the silica surface.

The ${ }^{13} \mathrm{C}$ CP MAS NMR of the functionalised material 4 (not shown) is very similar to that of the free ligand $\mathbf{1 a}$, in agreement with previous results $[14,19]$. A decrease in the intensity of the resonances of the $\mathrm{SiO}-\mathrm{CH}_{2} \mathrm{CH}_{3}$ group at $16.5 \mathrm{ppm}\left(\mathrm{CH}_{3}\right)$ and $58 \mathrm{ppm}\left(\mathrm{CH}_{2}\right)$ is observed since the binding of the ligand to the surface of the host material takes place by the hydrolysis of such groups. The quality of the spectra of the metal containing materials $\mathbf{5}, \mathbf{5}^{\prime}$ and $\mathbf{6}, \mathbf{6}^{\prime}$ is poor as a result of the paramagnetism of the complexes, but the position of the peaks can be determined. Thus, for materials $\mathbf{5}^{\prime}$ and $\mathbf{6}^{\prime}$ the peaks observed in the range $0-75 \mathrm{ppm}$ can be assigned to the $\mathrm{CH}_{2}$ and $\mathrm{CH}_{3}$ carbons of the propyl chain of the ligand 1a. In particular, in material $\mathbf{6}^{\prime}$ it is possible to assign some peaks, namely those at $9.6\left(\mathrm{SiCH}_{2}\right), 127.9$ (phenyl-C), and $192.3 \mathrm{ppm}(\mathrm{C}=\mathrm{O})$. The signals observed at around $100 \mathrm{ppm}$ can be assigned to the acac ligand. A similar assignment can be carried out for materials $\mathbf{5}$ and $\mathbf{6}$.

\subsubsection{Magnetic properties}

Magnetisation measurements were carried out in powder samples of non-supported complexes $\left[\mathrm{Mn}(\mathrm{acac})_{2}\right.$ $\left.\left\{\mathrm{Ph}-\mathrm{DAB}-\left(\mathrm{CH}_{2}\right)_{3} \mathrm{Si}(\mathrm{OEt})_{3}\right\}\right](\mathbf{2 a})$ and $[\mathrm{VO}(\mathrm{acac})\{\mathrm{Ph}-\mathrm{DAB}-$ $\left.\left.\left(\mathrm{CH}_{2}\right)_{3} \mathrm{Si}(\mathrm{OEt})_{3}\right\}\right] \mathrm{Cl}(\mathbf{3 a})$, as well as in the materials MCM$41 / \mathrm{Mn}(\mathrm{acac})_{2}\left[\mathrm{Ph}-\mathrm{DAB}-\left(\mathrm{CH}_{2}\right)_{3} \mathrm{Si}(\mathrm{OEt})_{3}\right](5), \mathrm{MCM}-41-\mathrm{L} /$
$\mathrm{Mn}(\mathrm{acac})_{2}\left(\mathbf{5}^{\prime}\right), \mathrm{MCM}-41 / \mathrm{VO}(\mathrm{acac})\left[\mathrm{Ph}-\mathrm{DAB}-\left(\mathrm{CH}_{2}\right)_{3} \mathrm{Si}(\mathrm{OEt})_{3}\right]$ (6), and MCM-41-L/VO(acac) $\left(6^{\prime}\right)$. The analysis of the data using the spin-Hamiltonian model showed that in all Mn based materials (Fig. 4), manganese core is in oxidation state II, with a spin $5 / 2$, showing a higher local symmetry than in the starting reagent $\mathrm{Mn}(\mathrm{acac})_{3}$, which displays local tetragonal symmetry (Jahn-Teller distortion) and spin 2. Mn concentrations obtained from the fitting procedure were $0.63 \%$ and $2.91 \%$ for materials $\mathbf{5}$ and $\mathbf{5}^{\prime}$, respectively, in good agreement with elemental analysis results (0.7 and $2.9 \mathrm{wt} \%$ for $\mathbf{5}$ and $\mathbf{5}^{\prime}$, respectively).

In the V(IV)-based materials (Fig. 5), with spin 1/2, such as in $\mathrm{VO}(\mathrm{acac})_{2}$, it is not possible to extract unambiguous information on the local symmetry of vanadium atoms from the fitting procedure. Vanadium concentrations

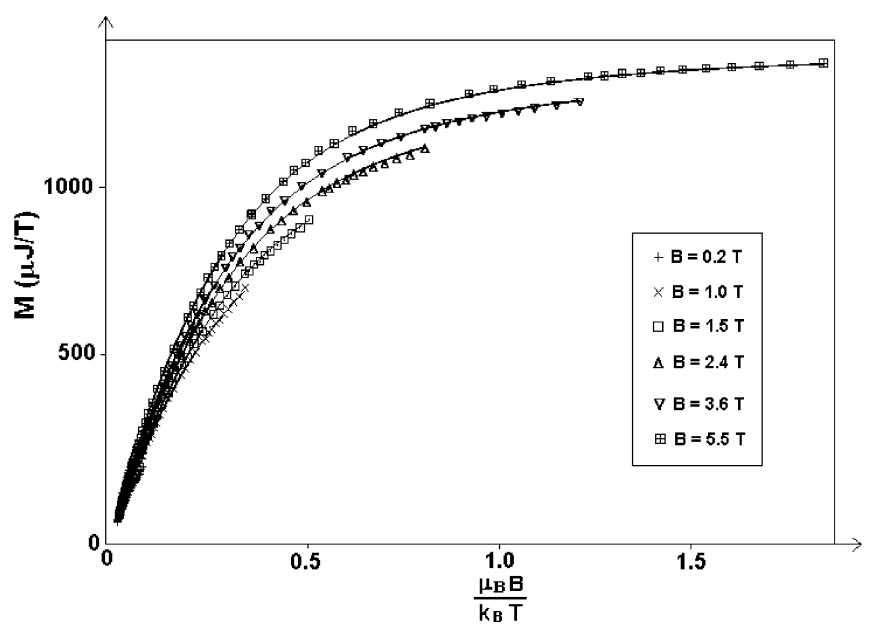

Fig. 4. Magnetisation of $\left[\mathrm{Mn}(\mathrm{acac})_{2} \mathrm{~L}\right]$ (2) plotted against $\mu_{\mathrm{B}} B / \mathrm{k}_{\mathrm{B}} \mathrm{T}$ collected at six different magnetic applied fields, between 2 and $200 \mathrm{~K}$, after subtraction of the diamagnetic fraction. The solid lines correspond to least square fitting with the spin-Hamiltonian model [28].

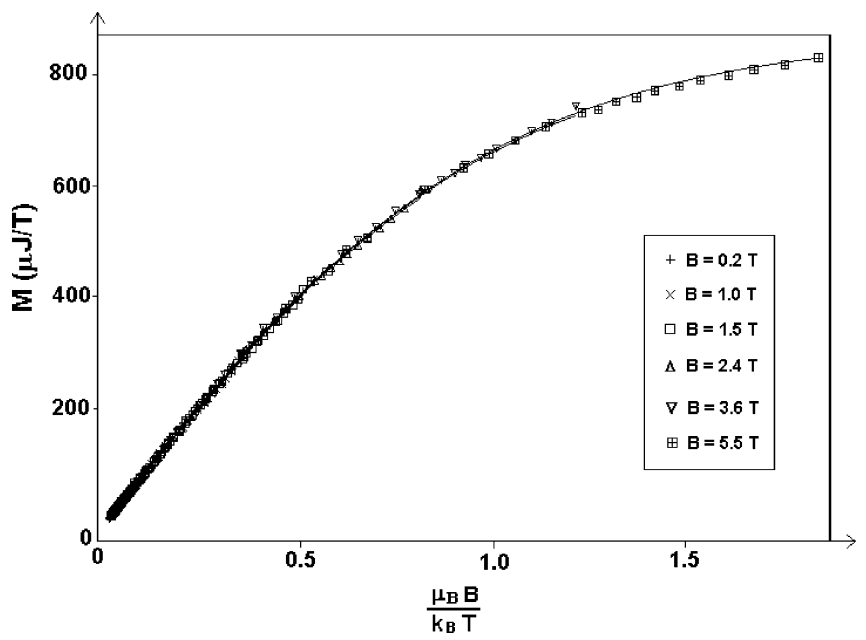

Fig. 5. Magnetisation of $[\mathrm{VO}(\mathrm{acac}) \mathrm{L}] \mathrm{Cl}$ (3) plotted against $\mu_{\mathrm{B}} B / \mathrm{k}_{\mathrm{B}} \mathrm{T}$ collected at six different magnetic applied fields, between 2 and $200 \mathrm{~K}$, after subtraction of the diamagnetic fraction. The solid lines correspond to least square fitting with the spin-Hamiltonian model [28]. 
obtained from the fitting procedure were $0.93 \%$ and $2.06 \%$ for $\mathbf{6}$ and $\mathbf{6}^{\prime}$, respectively, in reasonably good agreement with elemental analysis results $(0.8$ and $2.4 \mathrm{wt} \%$ for $\mathbf{6}$ and $\mathbf{6}^{\prime}$, respectively). The discrepancies observed for the concentration values may be related to the presence of adsorbed molecular oxygen, whose influence is significant for samples with small total magnetic moment. A series of measurements with highly diluted samples (very low concentration of the magnetic moments) are under progress in order to confirm the zero-field splitting parameters obtained, avoiding the presence of surface adsorbed molecular oxygen.

Results from DFT calculations for complexes $\mathbf{2 b}$ and $\mathbf{3 b}$ are in agreement with the findings described, predicting the spin density to lie essentially on the metal centres.

\subsubsection{Catalysis}

The manganese-containing materials, $\mathbf{2 a}, \mathbf{5}$ and $\mathbf{5}^{\prime}$ were tested as catalysts in the epoxidation of cis-cyclooctene using tert-butyl hydroperoxide $(t-\mathrm{BuOOH})$ as oxygen donor, at $328 \mathrm{~K}$. The reaction is very sluggish without catalyst or in the presence of MCM-41-L (4), giving a maximum of 5\% conversion after $24 \mathrm{~h}$ reaction. In the presence of $\mathbf{2 a}, \mathbf{5}$ or $\mathbf{5}^{\prime}, 21-27 \%$ conversion is achieved at $24 \mathrm{~h}$, under similar reaction conditions (Fig. 6a). The kinetic profiles obtained for these three catalysts are practically coincident, and they give quite similar initial turnover frequencies $(\mathrm{TOF}=1-6$ $\mathrm{mol} \cdot \mathrm{mol}_{\mathrm{Mn}}^{-1} \cdot \mathrm{h}^{-1}$, Table 3$)$. In all cases, as cyclooctene conversion increases selectivity to 1,2-epoxycyclooctane decreases significantly (drops to $50 \%$ as conversion tends to $30 \%$ ) in detriment of the formation of the corresponding 1,2-diol as the by-product (Fig. 6b). ICP-AES of the solids recovered after the reaction with $\mathbf{5}$ and $\mathbf{5}^{\prime}$ (by filtration, washing with $n$-hexane and drying at room temperature) indicated no measurable loss of $\mathrm{Mn}$. The catalytic activity of $\mathbf{2 a}, \mathbf{5}$ and $\mathbf{5}^{\prime}$ can be compared with that of a $\left[\mathrm{MoO}_{2} \mathrm{Cl}_{2} \mathrm{~L}\right]$ complex (MoL) with the same bidentate 1,4-diazabutadiene ligand $\left(\mathrm{L}=\mathrm{RN}=\mathrm{C}(\mathrm{Ph})-\mathrm{C}(\mathrm{Ph})=\mathrm{NR}, \mathrm{R}=\left(\mathrm{CH}_{2}\right)_{3} \mathrm{Si}(\mathrm{OEt})_{3}\right)$
Table 3

Epoxidation of cyclooctene with $t-\mathrm{BuOOH}$, in the presence of the transition metal catalysts, at $328 \mathrm{~K}$

\begin{tabular}{lclc}
\hline Catalyst & $\begin{array}{l}\text { Initial activity } \\
{\left[\mathrm{mol} \mathrm{mol}_{\mathrm{M}}^{-1} \mathrm{~h}^{-1}\right]^{\mathrm{a}}}\end{array}$ & $\begin{array}{l}\text { Conversion }^{\mathrm{b}} \\
(\%)\end{array}$ & $\begin{array}{l}\text { Selectivity }^{\mathrm{c}} \\
(\%)\end{array}$ \\
\hline $\mathbf{2 a}$ & 3 & 22 & 59 \\
$\mathbf{5}$ & 6 & 22 & 62 \\
$\mathbf{5}^{\prime}$ & 1 & 27 & 55 \\
$\mathbf{3 a}$ & 63 & 73 & 93 \\
$\mathbf{6}($ run 1) & 148 & 61 & 98 \\
$\mathbf{6}$ (run 2) & 23 & 61 & 98 \\
$\mathbf{6}$ (run 3) & 19 & 60 & 98 \\
$\mathbf{6}^{\prime}($ run 1) & 150 & 83 & 98 \\
$\mathbf{6}^{\prime}($ run 2) & 18 & 81 & 100 \\
$\mathbf{6}^{\prime}$ (run 3) & 18 & 81 & 100 \\
\hline
\end{tabular}

a Turnover frequency calculated at ca. $15 \mathrm{~min}$.

${ }^{b}$ Cyclooctene conversion after $24 \mathrm{~h}$.

${ }^{c}$ Selectivity to epoxide at $24 \mathrm{~h}$.

supported on MCM-41 (denoted MoL-MCM-41) using a similar grafting procedure [14]. A comparative study of the catalytic activity of $\mathbf{2 a}$ and $\mathbf{5}$ for cyclooctene epoxidation with that of MoL and MoL-MCM-41, respectively, shows that the Mn catalysts are less efficient than the Mo ones, under similar reaction conditions. For $2 \mathrm{a}$ and MoL TOF (calculated at $1 \mathrm{~h}$ reaction) is 2 and $15 \mathrm{~mol} \mathrm{~mol}_{\mathrm{M}}^{-1} \mathrm{~h}^{-1}$ and conversion after $24 \mathrm{~h}$ is $22 \%$ and $56 \%$, respectively, while for the MCM-41-supported complexes, 5 and $\mathrm{MoL}-$ MCM-41, TOF is 6 and $13 \mathrm{~mol} \mathrm{~mol}_{\mathrm{M}}^{-1} \mathrm{~h}^{-1}(M=\mathrm{Mn}, \mathrm{Mo})$ and conversion after $24 \mathrm{~h}$ is $22 \%$ and $65 \%$, respectively. On the other hand, the Mo catalysts are more selective to the epoxide ( $100 \%$ at ca. $25 \%$ conversion) than the Mn ones (ca. $55 \%$ at ca. $25 \%$ conversion).

The vanadium materials, $\mathbf{3 a}, \mathbf{6}$ and $\mathbf{6}^{\prime}$ were also tested as catalysts in the epoxidation of cyclooctene with $t-\mathrm{BuOOH}$, at $328 \mathrm{~K}$. 1,2-Epoxycyclooctane is the main reaction product formed in more than $98 \%$ selectivity at $61 \%$ and $83 \%$ conversion (at $24 \mathrm{~h}$ reaction) in the presence of $\mathbf{6}$ and $\mathbf{6}^{\prime}$, respectively (Fig. 6b). These results are better than those obtained for the Mn catalysts prepared in the present work,
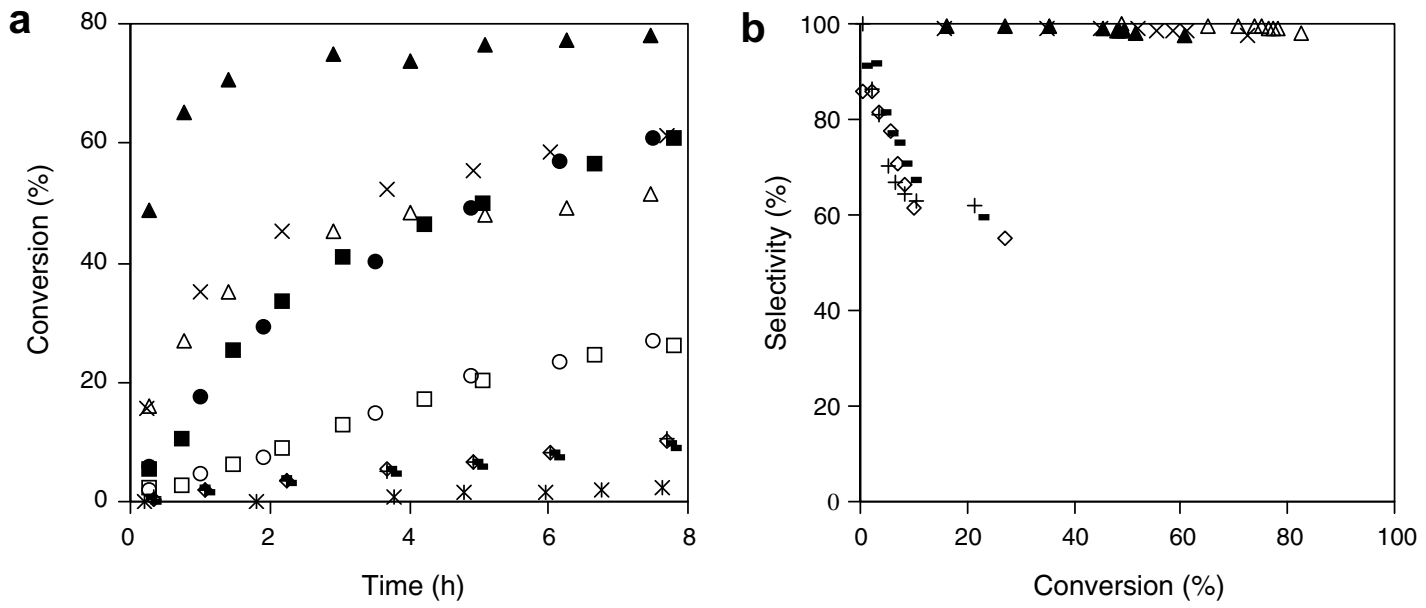

Fig. 6. Kinetic profiles: cyclooctene conversion (a) and selectivity to epoxide versus conversion (b) in the presence of compounds $4(*), \mathbf{2 a}(-), \mathbf{5}(+), \mathbf{5}^{\prime}$ $(\diamond), 3 a(\times), 6$ (open symbols: $(\triangle)$ - first run; $(\square)$ - reused once; $(\bigcirc)$ - reused twice) and $\mathbf{6}^{\prime}$ (solid symbols used for $\mathbf{6}$ ), using $t$-BuOOH. 
and than those reported in the literature for MoL and MoL-MCM-41, under similar reaction conditions: TOF calculated at $1 \mathrm{~h}$ is greater than $100 \mathrm{~mol} \mathrm{~mol}_{\mathrm{V}}^{-1} \mathrm{~h}^{-1}$ for $\mathbf{6}$ and $\mathbf{6}^{\prime}$, and equals $35 \mathrm{~mol} \mathrm{~mol}_{\mathrm{V}}^{-1} \mathrm{~h}^{-1}$ for $\mathbf{3 a}$, compared to 13 and $15 \mathrm{~mol} \mathrm{~mol}_{\mathrm{Mo}}^{-1} \mathrm{~h}^{-1}$ for MoL-MCM-41 and MoL, respectively [14].

The initial TOF is practically the same for $\mathbf{6}$ and $\mathbf{6}^{\prime}$ (148 and $150 \mathrm{~mol} \mathrm{~mol}_{\mathrm{V}}^{-1} \mathrm{~h}^{-1}$, respectively, Table 3). After ca. $15 \mathrm{~min}$, the reaction becomes faster in the presence of $\mathbf{6}^{\prime}$ than of $\mathbf{6}$, most likely due to the higher metal loading of the former (Fig. 6a). In the case of the unsupported complex 3a, TOF is significantly lower $\left(63 \mathrm{~mol} \mathrm{~mol}_{\mathrm{V}}^{-1} \mathrm{~h}^{-1}\right)$ than that of the supported catalysts $\mathbf{6}$ and $\mathbf{6}^{\prime}$. This somewhat contrasts with the Mn catalysts in that the unsupported Mn complex 2a possessed similar catalytic activity to that of the supported catalysts $\mathbf{5}$ and $\mathbf{5}^{\prime}$. Possibly, partial catalyst deactivation of $\mathbf{3 a}$ occurs to a relatively large extent, under the applied oxidising conditions.

The catalyst stability of $\mathbf{6}$ and $\mathbf{6}^{\prime}$ was examined by recycling the recovered solids (filtered, washed with $n$-hexane and dried at room temperature). Partial loss of catalytic activity is observed mainly from the first to the second reaction run (Table 3). Despite the lower initial reaction rate, after $24 \mathrm{~h}$ reaction, the conversion is practically the same as that achieved in the first run. These results may be due to changes in the nature of the active species and/or catalyst deactivation. Leaching tests were performed by filtering the reaction mixture at ca. $15 \mathrm{~min}$ to separate the solid at the reaction temperature and leaving the solution to react further. After $3 \mathrm{~h}$, the reaction without the solid catalyst proceeded to roughly the same extent as when filtration was not performed (conversion varied less than 5\% of that obtained without filtration). ICP-AES of the recovered solids showed no major change of the vanadium content in the case of $\mathbf{6}$. It is possible that small catalyst particles were not separated by the sintered glass filter used for the leaching experiments. However, changes in the nature of the surface metal species under the applied oxidising conditions cannot be ruled out. These results are comparable to that reported in the literature for MoL-MCM-41, in that no measurable metal leaching is observed [14]. In the case of $\mathbf{6}^{\prime}$, the $\mathrm{V}$ content decreased $36 \%$, suggesting that for this material loss of activity in consecutive runs is, at least in part, attributed to metal leaching under the applied reaction conditions.

\section{Conclusions}

The present work has revealed that (a) reaction of $\left[\mathrm{Mn}{ }^{\mathrm{III}}(\mathrm{acac})_{3}\right]$ and $\left[\mathrm{V}^{\mathrm{IV}} \mathrm{O}(\mathrm{acac})_{2}\right]$ with $\mathrm{Ph}-\mathrm{DAB}-\left(\mathrm{CH}_{2}\right)_{3} \mathrm{R}$ $\left[\mathrm{R}=\mathrm{Si}(\mathrm{OEt})_{3} ; \mathrm{H}\right](\mathrm{L})$ in methanol leads to complexes of the type $\left[\mathrm{Mn}^{\mathrm{II}}(\mathrm{acac})_{2} \mathrm{~L}\right]$ and $\left[\mathrm{V}^{\mathrm{IV}} \mathrm{O}(\mathrm{acac}) \mathrm{L}\right] \mathrm{Cl}$. In the manganese case, the addition of the neutral bidentate ligand facilitates the reduction of $\mathrm{Mn}$ (III) to $\mathrm{Mn}$ (II) [33]; (b) the 1,4-diazabutadiene ligand bearing triethoxysilyl groups is useful for the preparation of catalytically active manganese(II) and oxovanadium(IV) complexes that can be easily heterogenised on silica supports by covalent bonding. Similar materials were synthesised by the tethering method, by linking the bidentate ligand to the silica surface through stable covalent $\mathrm{Si}-\mathrm{O}-\mathrm{Si}$ bonds, and further reaction with $\left[\mathrm{Mn}(\mathrm{acac})_{3}\right]$ and $\left[\mathrm{VO}(\mathrm{acac})_{2}\right]$. A higher metal loading was achieved by this method, and the mesoporous regularity was not lost, but the channels seem to be significantly blocked.

The catalytic performance of the unsupported and MCM-41-supported complexes has been investigated in the oxidation of $c i s$-cyclooctene with $t$ - $\mathrm{BuOOH}$. The vanadium catalysts were more active and selective epoxidation catalysts than the corresponding Mn materials, and than the unsupported and MCM-41-supported molybdenum complexes bearing the same L ligand reported in the literature [14]. In the case of the Mn catalysts epoxide selectivity decreases significantly with conversion, and the corresponding 1,2-diol is formed. While the grafting procedure led to lower vanadium content than the tethering method, the grafted material is more stable towards metal leaching, which is an important issue for practical application of heterogeneous catalysts. However, partial loss of catalytic activity in consecutive reaction runs was observed for tethered and grafted catalysts, suggesting that other deactivation phenomena are involved (possibly, changes in the nature of the surface metal species).

\section{Acknowledgments}

The authors are grateful to POCI 2010, FEDER and FCT for financial support (POCI/CTM/55648/2004, POCI/QUI/58925/2004). CDN (SFRH/BPD/27344/2006) and PDV (SFRH/BPD/28149/2006) thank FCT for research grants.

\section{References}

[1] Y. Iwasawa, in: Y. Iwasawa, D. Riedel (Ed.), Tailored Metal Catalysts, Dordrecht, 1986, pp. 1-85.

[2] U. Deschler, P. Kleinschmit, P. Panster, Angew. Chem., Int. Ed. Engl. 25 (1986) 236.

[3] C.T. Kresge, M.E. Leonowicz, W.J. Roth, J.C. Vartuli, J.S. Beck, Nature 359 (1992) 710.

[4] J.S. Beck, J.C. Vartuli, W.J. Roth, M.E. Leonowicz, C.T. Kresge, K.D. Schmitt, C.T.-W. Chu, D.H. Olson, E.W. Sheppard, S.B. McCullen, J.B. Higgins, J.L. Schlenker, J. Am. Chem. Soc. 114 (1992) 10834.

[5] J.Y. Ying, C.P. Mehnert, M.S. Wong, Angew. Chem., Int. Ed. 38 (1999) 56.

[6] C.D. Nunes, A.A. Valente, M. Pillinger, A.C. Fernandes, C.C. Romão, J. Rocha, I.S. Gonçalves, J. Mater. Chem.12 (2002) 1735; C.D. Nunes, A.A. Valente, M. Pillinger, J. Rocha, I.S. Gonçalves, Chem. Eur. J. 9 (2003) 4380.

[7] C.D. Nunes, M. Pillinger, A.A. Valente, I.S. Gonçalves, J. Rocha, P. Ferreira, F.E. Kühn, Eur. J. Inorg. Chem. (2002) 1100.

[8] M. Pillinger, C.D. Nunes, P.D. Vaz, A.A. Valente, I.S. Gonçalves, P.J.A. Ribeiro-Claro, J. Rocha, L.D. Carlos, F.E. Kühn, Phys. Chem. Chem. Phys. 4 (2002) 3098.

[9] M.H. Valkenberg, W.F. Hölderich, Catal. Rev. 44 (2002) 321.

[10] D.M. Ford, E.E. Simanek, D.F. Shantz, Nanotechnology 16 (2005) S458. 
[11] M. Jia, W.R. Thiel, Chem. Commun. (2002) 2392; M. Jia, A. Seifert, W.R. Thiel, Chem. Mater. 15 (2003) 2174; M. Jia, A. Seifert, W.R. Thiel, J. Catal. 221 (2004) 319; M. Jia, A. Seifert, M. Berger, H. Giegengack, S. Schulze, W.R. Thiel, Chem. Mater. 16 (2004) 877.

[12] P. Ferreira, I.S. Gonçalves, F.E. Kühn, A.D. Lopes, M.A. Martins, M. Pillinger, A. Pina, J. Rocha, C.C. Romão, A.M. Santos, T.M. Santos, A.A. Valente, Eur. J. Inorg. Chem. (2000) 2263.

[13] S. Gago, Y. Zhang, A.M. Santos, K. Köhler, F.E. Kühn, J.A. Fernandes, M. Pillinger, A.A. Valente, T.M. Santos, P.J.A. RibeiroClaro, I.S. Gonçalves, Micropor. Mesopor. Mater. 76 (2004) 131; S.M. Bruno, J.A. Fernandes, L.S. Martins, I.S. Gonçalves, M. Pillinger, P. Ribeiro-Claro, J. Rocha, A.A. Valente, Catal. Today 114 (2006) 263.

[14] C.D. Nunes, M. Pillinger, A.A. Valente, J. Rocha, A.D. Lopes, I.S Gonçalves, Eur. J. Inorg. Chem. (2003) 3870; C.D. Nunes, M. Pillinger, A.A. Valente, A.D. Lopes, I.S. Gonçalves, Inorg. Chem. Commun. 6 (2003) 1228.

[15] K. Wieghardt, Angew. Chem., Int. Ed. Engl. 28 (1989) 1153; V.L. Pecoraro (Ed.), Manganese Redox Enzymes, VCH, New York, 1992;

G.C. Dismukes, Chem. Rev. 96 (1996) 2909.

[16] J. Inorg. Biochem. 80 (2000) (special issue dedicated to biological aspects of vanadium).

[17] Z. Luan, J. Xu, L. Kevan, Chem. Mater. 10 (1998) 3699.

[18] P. Sutra, D. Brunel, Chem. Commun. (1996) 2485.

[19] J. Gimenez, C.D. Nunes, P.D. Vaz, A.A. Valente, P. Ferreira, M.J. Calhorda, J. Mol. Catal. A: Chem. 256 (2006) 90.

[20] R.G. Charles, Inorg. Syn. 6 (1960) 164.

[21] M. Bhattacharjee, J. Chem. Res. (S) (1992) 415.

[22] R.G. Parr, W. Yang, Density Functional Theory of Atoms and Molecules, University Press, Oxford, New York, 1989.

[23] M.J. Frisch, G.W. Trucks, H.B. Schlegel, G.E. Scuseria, M.A. Robb, J.R. Cheeseman, J.A. Montgomery Jr., T. Vreven, K.N. Kudin, J.C. Burant, J.M. Millam, S.S. Iyengar, J. Tomasi, V. Barone, B. Mennucci, M. Cossi, G. Scalmani, N. Rega, G.A. Petersson, H. Nakatsuji, M. Hada, M. Ehara, K. Toyota, R. Fukuda, J. Hasegawa, M. Ishida, T. Nakajima, Y. Honda, O. Kitao, H. Nakai, M. Klene, X. Li, J.E. Knox, H.P. Hratchian, J.B. Cross, V. Bakken, C. Adamo, J. Jaramillo, R. Gomperts, R.E. Stratmann, O. Yazyev, A.J. Austin, R. Cammi, C. Pomelli, J.W. Ochterski, P.Y. Ayala, K. Morokuma, G.A.
Voth, P. Salvador, J.J. Dannenberg, V.G. Zakrzewski, S. Dapprich, A.D. Daniels, M.C. Strain, O. Farkas, D.K. Malick, A.D. Rabuck, K. Raghavachari, J.B. Foresman, J.V. Ortiz, Q. Cui, A.G. Baboul, S. Clifford, J. Cioslowski, B.B. Stefanov, G. Liu, A. Liashenko, P. Piskorz, I. Komaromi, R.L. Martin, D.J. Fox, T. Keith, M.A. AlLaham, C.Y. Peng, A. Nanayakkara, M. Challacombe, P.M.W. Gill, B. Johnson, W. Chen, M.W. Wong, C. Gonzalez, J.A. Pople, Gaussian 03, Revision B.04, Gaussian, Inc., Wallingford, CT, 2004.

[24] F.H. Allen, Acta Crystallogr. B58 (2002) 380.

[25] A.D. Becke, J. Chem. Phys. 98 (1993) 5648;

B. Miehlich, A. Savin, H. Stoll, H. Preuss, Chem. Phys. Lett. 157 (1989) 200;

C. Lee, W. Yang, G. Parr, Phys. Rev. B. 37 (1988) 785.

[26] T.H. Dunning Jr., P.J. Hay, in: H.F. Schaefer (Ed.), Modern Theoretical Chemistry, vol. 3, Plenum, New York, 1976, pp. 1-28; P.J. Hay, W.R. Wadt, J. Chem. Phys. 82 (1985) 270; W.R. Wadt, P.J. Hay, J. Chem. Phys. 82 (1985) 284; P.J. Hay, W.R. Wadt, J. Chem. Phys. 82 (1985) 299.

[27] A.D. McClean, G.S. Chandler, J. Chem. Phys. 72 (1980) 5639; R. Krishnan, J.S. Binkley, R. Seeger, J.A. Pople, J. Chem. Phys. 72 (1980) 650;

A.J.H. Wachters, J. Chem. Phys. 52 (1970) 1033;

P.J. Hay, J. Chem. Phys. 66 (1977) 4377;

K. Raghavachari, G.W. Trucks, J. Chem. Phys. 91 (1989) 1062;

R.C. Binning, L.A. Curtiss, J. Chem. Phys. 103 (1995) 6104;

M.P. McGrath, L. Radom, J. Chem. Phys. 94 (1991) 511.

[28] E.P. Day, Methods Enzymol. 227 (1993) 437.

[29] A.A. Romero, M.D. Alba, W. Zhou, J. Klinowski, J. Phys. Chem. B 101 (1997) 5294;

J. Xu, Z. Luan, H. He, W. Zhou, L. Kevan, Chem. Mater. 10 (1998) 3690.

[30] B. Marler, U. Oberhagemann, S. Voltmann, H. Gies, Micropor. Mater. 6 (1996) 375;

W. Hammond, E. Prouzet, S.D. Mahanti, T.J. Pinnavaia, Micropor. Mesopor. Mater. 27 (1999) 19.

[31] S.J. Gregg, K.S.W. Sing, Adsorption, Surface Area and Porosity, second ed., Academic Press, London, 1982.

[32] M.D. Alba, A. Becerro, J. Klinowski, J. Chem. Soc., Faraday Trans. 92 (1996) 849.

[33] R. van Gorkum, E. Bouwman, J. Reedijk, Inorg. Chem. 43 (2004) 2456. 